\title{
Global distribution of the intensity and frequency of hourly precipitation and their responses to ENSO
}

\author{
Xiao-Feng $\mathrm{Li}^{1}$ - Stephen Blenkinsop ${ }^{1}$ - Renaud Barbero ${ }^{1,2}$ - Jingjing $\mathrm{Yu}^{1}$ - Elizabeth Lewis ${ }^{1}$. Geert Lenderink ${ }^{3}$. \\ Selma Guerreiro ${ }^{1}$. Steven Chan ${ }^{1}$ - Yafei $\mathrm{Li}^{1,5}$. Haider Ali ${ }^{1}$. Roberto Villalobos Herrera ${ }^{1}$ - Elizabeth Kendon ${ }^{4}$. \\ Hayley J. Fowler ${ }^{1}$
}

Received: 5 November 2019 / Accepted: 18 April 2020 / Published online: 30 April 2020

(c) The Author(s) 2020

\begin{abstract}
We investigate the global distribution of hourly precipitation and its connections with the El Niño-Southern Oscillation (ENSO) using both satellite precipitation estimates and the global sub-daily rainfall gauge dataset. Despite limited moisture availability over continental surfaces, we find that the highest mean and extreme hourly precipitation intensity (HPI) values are mainly located over continents rather than over oceans, a feature that is not evident in daily or coarser resolution data. After decomposing the total precipitation into the product of the number of wet hours (NWH) and HPI, we find that ENSO modulates total precipitation mainly through the $\mathrm{NWH}$, while its effects on HPI are more limited. The contrasting responses to ENSO in NWH and HPI is particularly apparent at the rising branches of the Pacific and Atlantic Walker Circulations, and is also notable over land-based gauges in Australia, Malaysia, the USA, Japan and Europe across the whole distribution of hourly precipitation (i.e. extreme, moderate and light precipitation). These results provide new insights into the global precipitation distribution and its response to ENSO forcing.
\end{abstract}

Keywords ENSO $\cdot$ Precipitation total $\cdot$ Number of wet hours $\cdot$ Hourly precipitation intensity $\cdot$ Hourly precipitation frequency $\cdot$ Walker circulation $\cdot$ Hourly precipitation extreme

\section{Introduction}

Electronic supplementary material The online version of this article (https://doi.org/10.1007/s00382-020-05258-7) contains supplementary material, which is available to authorized users.

Xiao-Feng Li

Xiaofeng.Li@newcastle.ac.uk

1 School of Engineering, Newcastle University, Newcastle upon Tyne NE1 7RU, UK

2 French National Research Institute for Agriculture, Food and Environment, RECOVER, Aix-en-Provence, France

3 Royal Netherlands Meteorological Institute, De Bilt, The Netherlands

4 Met Office Hadley Centre, FitzRoy Road, Exeter, UK

5 State Key Laboratory of Earth Surface Processes and Resource Ecology, Faculty of Geographical Science, Beijing Normal University, Beijing, China
As the dominant source of natural climate variability in tropical regions on inter-annual timescales, the El Niño-Southern Oscillation (ENSO) influences precipitation variability on a global scale (e.g., Ropelewski and Halpert 1987; Dai et al. 1997; Dai and Wigley 2000; Alexander et al. 2002; Lyon and Barnston 2005; Trenberth and Shea 2005; Allan and Soden 2008; Pui et al. 2012; Huang and Xie 2015; Gu and Adler 2018). ENSO has thus been described as "the single most important determinant of variability in global precipitation fields" (Dai et al. 1997; Dai and Wigley 2000), which modulates global precipitation variability through both thermal and dynamical forces (e.g., Seager et al. 2010, 2011; Huang et al. 2013; Power et al. 2013; Chung and Power 2014; Chung et al. 2014; Huang 2014; Huang and Xie 2015).

In recent decades, increased attention has focused on responses of daily precipitation extremes to ENSO variability (e.g., Gershunov and Barnett 1998; Huffman et al. 2001; Alexander et al. 2006; Curtis et al. 2007; Allan and Soden 
2008; Grimm and Tedeschi 2009; Zhang et al. 2010; Xuereb and Jakob 2014; Lestari et al. 2016; Whan and Zwiers 2016). Allan and Soden (2008) demonstrated that tropical daily precipitation extremes are also influenced by alternating warm and cold episodes of ENSO. During the warm (cold) phase of ENSO, i.e. El Niño (La Niña), most of the tropical ocean surface are warmer (cooler) than normal, and the atmosphere is charged with more (less) moisture, resulting in more (less) extreme daily precipitation events over the (combined land and ocean) tropical region. These results are evident in both satellite observations and climate simulations (Allan and Soden 2008), indicating that ENSO is a major driver modulating daily precipitation extremes in the tropics on interannual timescales.

However, the impacts of ENSO on tropical daily precipitation extremes are different when considering only land areas (Allan and Soden 2008). Curtis et al. (2007) suggested that this might be due to the juxtaposition of tropical land areas with the ascending branches of the Walker Circulation, the zonal and vertical atmospheric circulation component of the ENSO. The contrasting impacts of ENSO over land and ocean areas on daily precipitation extremes have been verified in regional analyses. For example, Xuereb and Jakob (2014) reported decreased (increased) frequency of daily precipitation extremes during El Niño (La Niña) years over most of Australia. Lestari et al. (2016) also documented that the frequency of daily precipitation extremes was significantly higher during La Niña than El Niño years in transitional seasons over the eastern Indonesian Maritime Continent.

A number of efforts have also been made to identify ENSO's impacts on extra-tropical daily precipitation extremes. ENSO was found to influence significantly the frequency of daily precipitation extremes across parts of North America (Gershunov and Barnett 1998; Zhang et al. 2010; Whan and Zwiers 2016) and South America (Grimm and Tedeschi 2009) through tropical-extratropical atmospheric teleconnections.

However, most of these studies have been focused on daily precipitation extremes, and little is known about the impacts of ENSO on shorter-duration precipitation, especially on hourly precipitation. This is of particular importance as unlike other meteorological variables, precipitation is generally localized in space and highly intermittent (e.g., Trenberth et al. 2017). This intermittency is better manifested in hourly precipitation measurements relative to daily, monthly or other coarser resolutions. Global hourly precipitation data could thus provide new insights on both the frequency and intensity of global short-duration precipitation (mean and extremes) and their responses to ENSO variability.

Global analyses of hourly precipitation are still limited (e.g., Trenberth et al. 2017; Barbero et al. 2019b) although a number of studies have now focused on regional or continental hourly precipitation (e.g., Lenderink and Van Meijgaard 2008; Yu and Li 2012; Kendon et al. 2014; Blenkinsop et al. 2015; Chan et al. 2016; Luo et al. 2016; Ali and Mishra 2017; Barbero et al. 2017, 2019a; Prein et al. 2017; Lenderink et al. 2017; Guerreiro et al. 2018; Moron et al. 2019). However, to date, the basic features of global hourly precipitation (including frequency and intensity) have not been documented systematically on a global scale.

Since the 1990s, global gridded high-resolution subhourly satellite precipitation estimates have been developed, e.g., the 30-min, $8 \mathrm{~km}$ resolution CMORPH global satellite precipitation dataset (Joyce et al. 2004). This dataset offers global coverage and extends back to 1998, which provides valuable information for the analysis of global hourly precipitation climatology, including extremes (e.g., Curtis et al. 2007; Sun et al. 2018; Zorzetto and Marani 2019). Additionally, an increasing number of weather stations have recorded precipitation on sub-daily time steps, enabling new, global-scale analyses. The "INTElligent use of climate models for adaptation to Non-Stationary hydrological Extremes" (INTENSE ${ }^{1}$ ) project (Blenkinsop et al. 2018) has recently collected and quality-controlled records from more than 23,687 rain gauges recording sub-daily precipitation, named the Global Sub-Daily Rainfall dataset (GSDR) (Lewis et al. 2019). These two new datasets provide fresh opportunities for this study to examine the global patterns of hourly precipitation means and extremes and their modulation by ENSO.

The remainder of this paper is organized as follows. Section 2 presents the data and methods. Section 3 illustrates the basic features of global hourly precipitation. Section 4 shows the global contrasting patterns of mean frequency and intensity of hourly precipitation from CMORPH and gauge data induced by ENSO variability. In Sect. 5, we further examine the responses at multiple hourly precipitation intensities, ranging from light to extreme precipitation. Finally, the discussion and summary are presented in Sect. 6 .

\section{Data and methods}

\subsection{Hourly precipitation data: CMORPH and GSDR}

This study uses both global hourly satellite data and gauge data. Here, we use CMORPH v1.0 (Joyce et al. 2004; Joyce

\footnotetext{
1 INTENSE: "INTElligent use of climate models for adaptation to Non-Stationary hydrological Extremes" (ERC Consolidators Grant) provides the funded core of a community effort into the collection and analysis of sub-daily precipitation data and model outputs since 2015, which is led by Professor Hayley J. Fowler. For more details see https://research.ncl.ac.uk/intense/aboutintense/ and Blenkinsop et al. (2018).
} 
and Xie, 2011), a satellite data product developed by using CPC Morphing technique (Joyce et al. 2004) that blends microwave and infrared information, available at $\sim 8 \mathrm{~km}$ spatial $\left(0.07277^{\circ} \times 0.07277^{\circ}\right)$ and 30 -min temporal resolution, from $60^{\circ} \mathrm{N}$ to $60^{\circ} \mathrm{S}$ for January 1998 to February 2017. Although potential biases and artifacts due to satellite data or algorithm retrievals have been documented (e.g., Liu and Allan 2012; Roca 2019), including CMORPH (e.g., Masunaga et al. 2019), CMORPHv1.0 has been shown to perform better at representing daily and 3-h precipitation than TRMM 3B42 over many regions of the globe (Shen et al. 2010). CMORPH has also been used as the reference data source in developing regional merged hourly precipitation data products over land areas, including the first generation of a $0.1^{\circ} \times 0.1^{\circ}$ satellite-gauge blended hourly precipitation product over China (e.g., Shen et al. 2014). For our analysis, we first degraded the CMORPH data to an hourly $0.25^{\circ}$ resolution version by an averaging of native grid cells falling into the $0.25^{\circ}$ grid cell (Joyce et al. 2004; Yu et al. 2013; Shen et al. 2014; Yu et al. 2015). The CMORPH 3-hourly and daily precipitation data with $0.25^{\circ}$ resolution were also used for comparison with the hourly precipitation climatology.

We complemented our analysis with the GSDR dataset (Lewis et al. 2019; Barbero et al. 2019a, b), which provides a direct measure of precipitation. Although the data is relatively sparse and limited to specific regions of the world, it provides the opportunity to validate results based on satellite data and enhances the reliability of our conclusions, at least across continental regions. Here, we select 4663 hourly gauges covering the 10-year period from January 1998-February 2008 with less than $30 \%$ of missing values in the whole period (Figure $\mathrm{S} 1$ in the Supplementary Information).

\subsection{ENSO definition}

We use the Niño3.4 index to represent the phase and intensity of ENSO. The Niño3.4 index is calculated as the average sea surface temperature (SST) anomalies over the area $\left(5^{\circ} \mathrm{N}-5^{\circ} \mathrm{S}, 170^{\circ} \mathrm{W}-120^{\circ} \mathrm{W}\right)$ from HadISST V1.1 (Rayner et al. 2003).

\subsection{Definitions of precipitation statistics}

We examine a range of precipitation statistics including:

1. Wet hour: Hour where the precipitation amount exceeds $0.01 \mathrm{~mm}$ (Shen et al. 2014). Be note that, $0.01 \mathrm{~mm}$ is mainly specified to filter out the hours without precipitation in CMPORH data, the GSDR has a coarser resolution and its minimum precipitation amount is much larger than $0.01 \mathrm{~mm}$.
2. Number of wet hours (NWH): The total number of wet hours over a stated time span.

3. Hourly precipitation frequency of exceedance (HPF): The HPF is the number of hours during a given period with precipitation amount exceeding a certain percentile of the wet hour distribution. The units of the HPF is hours month ${ }^{-1}$. The sum of the HPF across the whole distribution equals to the NWH.

4. Hourly precipitation intensity (HPI): The HPI refers to the average hourly precipitation amount for all wet hours during a time period. The units of the HPI is $\mathrm{mm} \mathrm{h}^{-1}$.

5. Accumulated precipitation total (APT): The APT refers to the total precipitation amount from all hours (exceeding $0.01 \mathrm{~mm}$ ) over a stated time span. The units of APT is $\mathrm{mm} \mathrm{month}{ }^{-1}$, so the production of HPI $\left(\mathrm{mm} \mathrm{h}^{-1}\right)$ and NWH $\left(\mathrm{h}\right.$ month $\left.^{-1}\right)$ is exactly equal to the APT $\left(\mathrm{mm} \mathrm{month}{ }^{-1}\right)$ in all seasons including the annual mean.

It should be noted that the product of the NWH and the HPI gives the APT.

\subsection{HPF and HPI at different percentile levels}

The HPI in any calendar month $m(m=1,2, \ldots, 12)$ of a given year $y(y=1998,1999, \ldots)$ at $i t h(i=1,2, \ldots, 99)$ percentile, $H P I_{i t h, m, y}$, is simply defined as the value corresponding to a given percentile of all precipitation amounts of wet hours in that given month (month $m$ of year $y$ ). Similarly, the HPF of any calendar month $(m)$ in a given year $(y)$ above $i$ th percentile (of precipitation amounts of wet hours), $H P F_{i t h, m, y}$, is defined as the number of hours exceeding the climatological percentile $\left(C P_{i t h, m}\right)$.

The $i$ th climatological percentile value of a given month $m(m=1,2, \ldots, 12), C P_{i t h, m}$, is calculated based on precipitation amounts of all wet hours in the month $(m)$ during the 19-year-period of 1998-2016 (10-yearperiod of 1998-2007) for CMORPH (GSDR) data. In other words, $H P F_{i t h, m, y}$ was computed in different years with respect to the same reference percentile $\left(C P_{i t h, m}\right)$ for a given month that yields reliable year-to-year variability.

The indices of $H P F_{i t h, m, y}$ and $H P I_{i t h, m, n}$ for CMORPH (GSDR) data are calculated on a monthly timescale from January 1998 to February 2017 (2008) for each grid cell (gauge).

\subsection{Percentile bins}

To investigate the whole distribution of hourly precipitation, we also use the NWH allocated to a percentile bin $\left(H P F_{b, m, y}\right)$, following Allan and Soden (2008). Considering precipitation above $0.01 \mathrm{~mm} \mathrm{~h}^{-1}$, five percentile bins of precipitation rate at each grid-point were calculated, ranging 
from the lightest $20 \%$ to the heaviest $20 \%(0-20 \%, 20-40 \%$, $40-60 \%, 60-80 \%$, and $80-100 \%)$. In addition, the heaviest $20 \%$ of hourly precipitation events were further partitioned into $80-90 \%$ and $90-100 \%$ bins. Specifically, the bins $0-20 \%, 40-60 \%, 80-100 \%$ and $90-100 \%$ represent the HPF of 'light', 'moderate', 'heavy' and 'very heavy' precipitation, respectively, which correspond to the HPIs represented by the 10th, 50th, 90th and 95th percentiles, respectively.

\subsection{Pearson correlation}

To investigate the relationship between hourly precipitation and ENSO, we calculated the Pearson correlations between the Niño3.4 index and NWH, HPI using both the CMORPH and GSDR data separately on a seasonal basis. The efficient number of degrees of freedom (Zar 1984; Li et al. 2013) was taken into account when testing the significance of the Pearson correlation coefficients.

Here, we define summer as June-July-August (JJA), winter as December-January-February (DJF), and so on. The winter season in year $n$ is defined as December in year $n$ and January-February in year $n+1$. We analyze results for individual months within a season rather than using seasonal means, for example, in winter season, we use values for the three individual months of December, January, and February instead of their mean. This increases the sample size from 19 (10) to 57 (30) for each season for CMORPH (GSDR) data. Similar results were found using Spearman rank correlations (not shown) and composite analysis of El Niño and La Niña 'events' (as in Guerreiro et al. 2018) (see Sect. 5 of the Supplementary Information).

\section{Climatology of global distributions of hourly precipitation}

\subsection{Intensity}

A remarkable feature of the global hourly precipitation is the land-sea contrast, with highest climatological mean and extreme HPIs over land areas rather than oceanic areas. For example, the climatological mean HPI reaches over $1.5 \mathrm{~mm} \mathrm{~h}^{-1}$ in most seasons over tropical mid-west Africa, the eastern half of Northern America, and the southeast of South America in the extratropical latitudes, much heavier than the HPI over tropical oceans reaching a maximum of $\sim 1.1 \mathrm{~mm} \mathrm{~h}^{-1}$. Similar seasonal high HPI centers are observed over other land areas, e.g., northern Australia in austral summer (DJF, Fig. 1a) and southern and eastern Asia in austral winter (JJA, Fig. 1c). Moreover, extreme HPI represented by the climatological 99th percentile (Fig. 2) shows a similar spatial distribution to that of climatological-averaged HPI, with an exacerbated ocean-land contrast, featuring precipitation intensity exceeding $15 \mathrm{~mm} \mathrm{~h}^{-1}$ over land areas. This land-sea contrast feature is unexpected given that land areas are moisture-limited and that winds generally weaken over continents.

It should be noted that this land-sea contrast feature is less evident in daily or coarser resolution precipitation data. As shown in Fig. 3, the land-sea contrast seen in hourly data (Fig. 3a, d) becomes less evident in 3-h data (Fig. 3b, e), and is even nearly reversed in daily data (Fig. 3c, f, also see Figure S2 and S3 of the Supplementary Information). Indeed, mean and extreme HPI are higher across the tropical oceans when accumulated across daily time steps (except in Southern America). Thus, the land-sea contrast is a feature pertaining to hourly precipitation that cannot be detected in coarser resolutions. Further study on sub-hourly timescales may also reveal spatial features in precipitation intensity that are not apparent in hourly resolutions (Table 1).

\subsection{Frequency}

This land-sea contrast of climatological-averaged HPI contrasts with the distribution of the climatological-averaged NWH (Fig. 4) or the climatological-averaged accumulated precipitation total (APT, Figure S4 in Sect. 3 in the Supplementary Information) featuring higher values over oceanic areas than over the land areas (Fig. 4 vs Figure S4). This implies that the climatological-averaged APT is mainly determined by the NWH rather than the HPI. To quantify the similarity of APT with HPI and NWH, we computed the spatial correlation coefficients between each pair. Table 1 indicates that the similarities (represented by the spatial correlation) of the NWH with APT are much higher than those for HPI with APT in all four seasons. This demonstrates that the accumulated seasonal and annual rainfall totals are driven by the frequency of hourly rainfall rather than its intensity.

\section{Global contrasting responses of hourly precipitation frequency and intensity to ENSO}

The influence of ENSO on total precipitation is now well documented (see more details in Figure S5 and Sect. 3 in the Supplementary Information). However, its influence on the NWH and HPI is still unclear. Here, we get similar results by using both the GSDR data and the CMORPH data.

\subsection{Contrasting responses in CMORPH data}

Comparing the correlations between the Niño3.4 index and NWH (Fig. 5, left column) and HPI (Fig. 5, right column) in 


\section{Climatological Hourly Precipitation Intensity $\left(\mathrm{mm} \mathrm{hour}^{-1}\right)$}

(a) DJF

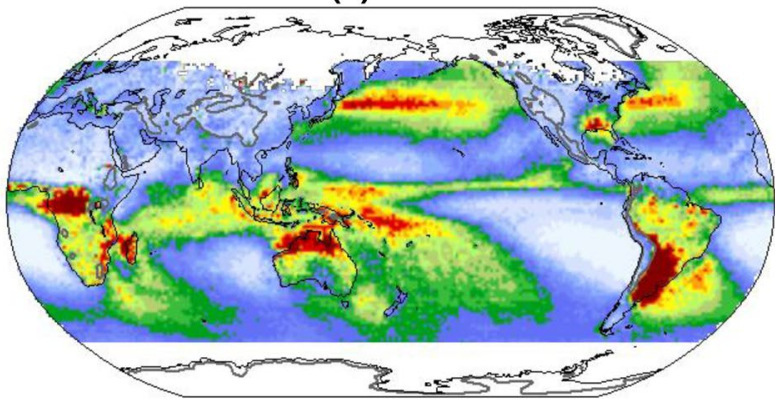

(c) JJA

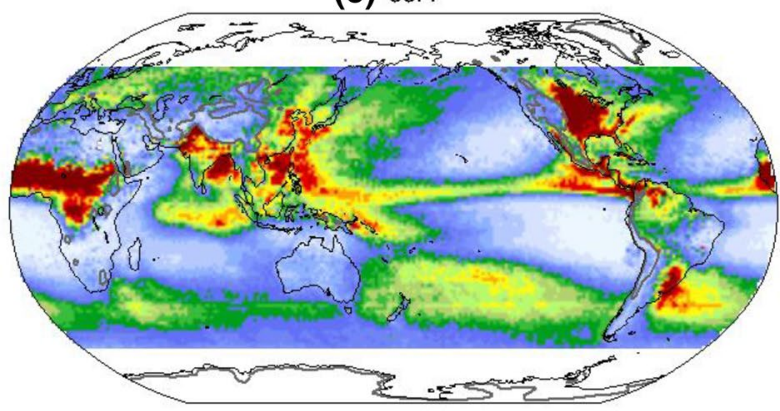

(b) MAM

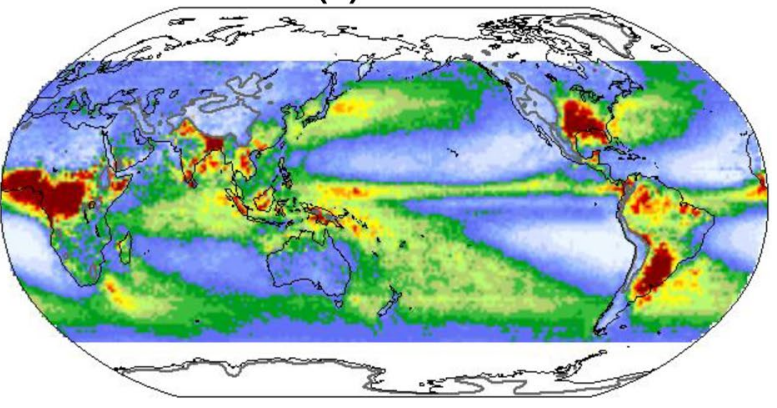

(d) $\mathrm{SON}$

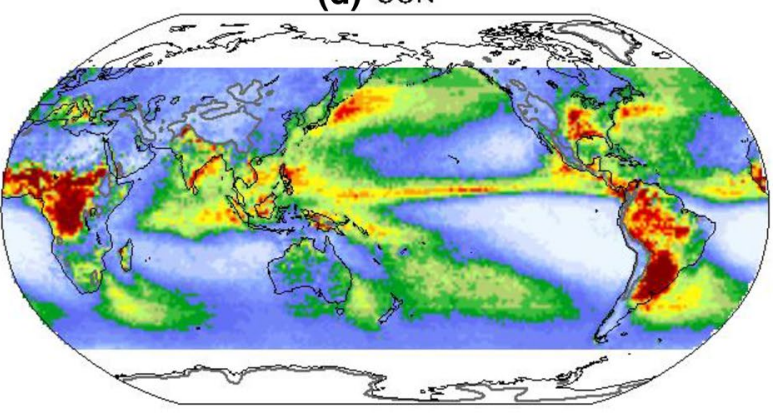

(e) Ann

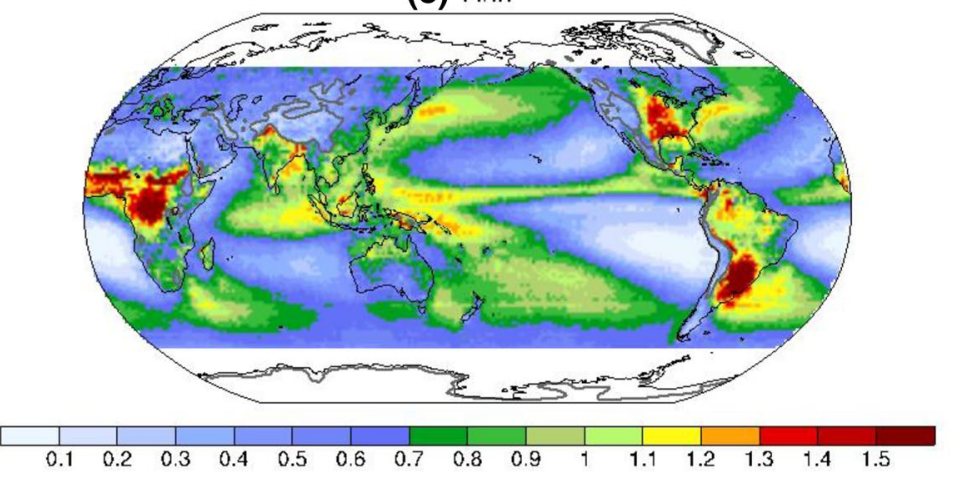

Fig. 1 Climatological-averaged hourly precipitation intensity (HPI; $\mathrm{mm} \mathrm{h}^{-1}$ ) retrieved from CMORPH hourly precipitation data for January 1998-February 2017 for a winter (DJF), b spring (MAM), c summer (JJA), d autumn (SON), and e the annual mean

CMORPH data, we find that NWH is much more sensitive to ENSO than HPI, especially in the tropics over the two rising branches of the Pacific and Atlantic Walker Circulations, i.e. for the tropical western Pacific (TWP) and tropical South America (TSA), where the significant negative correlations between Niño3.4 and NWH degrade for HPI (Fig. 5a, c, e, $\mathrm{g}$ vs $5 \mathrm{~b}, \mathrm{~d}, \mathrm{f}, \mathrm{h})$. This difference is exacerbated in winter (Fig. 5a vs 5b) and autumn (Fig. $5 \mathrm{~g}$ vs $5 \mathrm{~h}$ ), during the mature phases of ENSO, suggesting that El Niño (La Niña) conditions inhibit (promote) the NWH over the rising branches of the Walker Circulations (north of Australia and over tropical South America) but have only limited effects on the HPI.

In contrast, over sinking branches of the PWC, i.e. over the tropical mid-eastern Pacific (TMEP) (Fig. 5c), ENSO has a similar effect on both the NWH and the HPI. Moreover, the correlations with HPI are slightly stronger than with the $\mathrm{NWH}$, suggesting that the increase (decrease) in total precipitation at the sinking branch of the PWC in response to El Niño (La Niña) conditions may be attributed to the increase (decrease) of both the NWH and the HPI.

We quantify the above contrasting responses over the rising branches and the similar responses over the sinking branches of the Walker Circulation by separately calculating the average correlation across all grid cells between the Niño3.4 index and the NWH or HPI in the TWP (Fig. 6a), the TSA (Fig. 6b) and the TMEP (Fig. 6c) domains. The different responses of NWH and HPI to ENSO variability are clear over both the TWP (Fig. 6a) and the TSA 


\section{Climatological 99th Percentile $\left(\mathrm{mm} \mathrm{hour}^{-1}\right)$}

(a) DJF

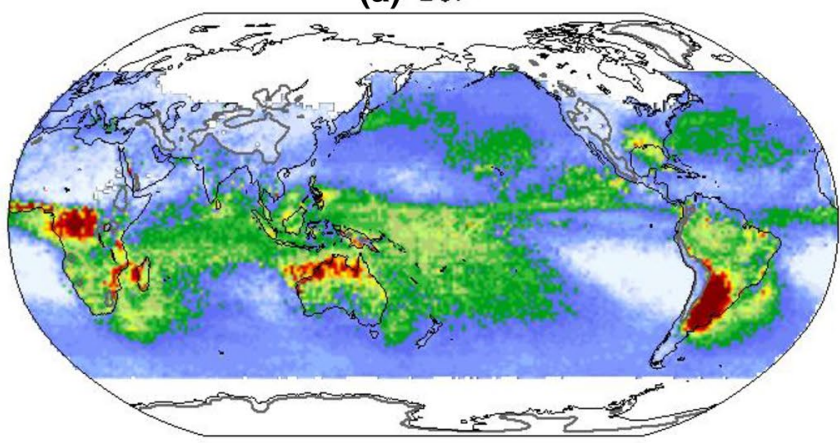

(c) JJA

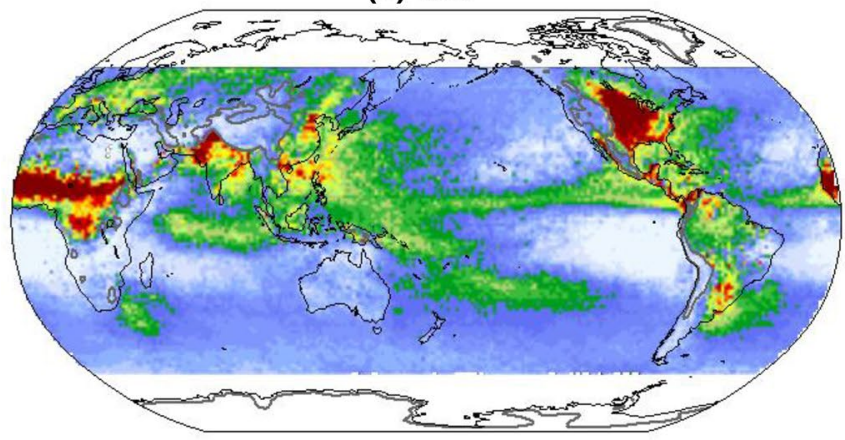

(b) MAM

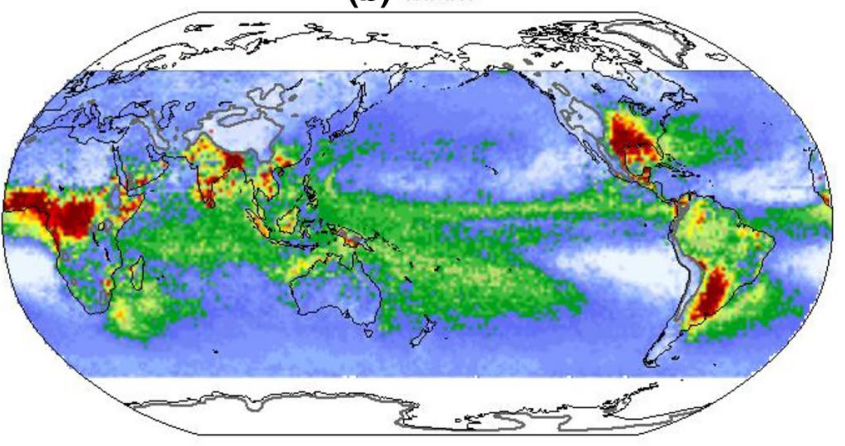

(d) $\mathrm{SON}$

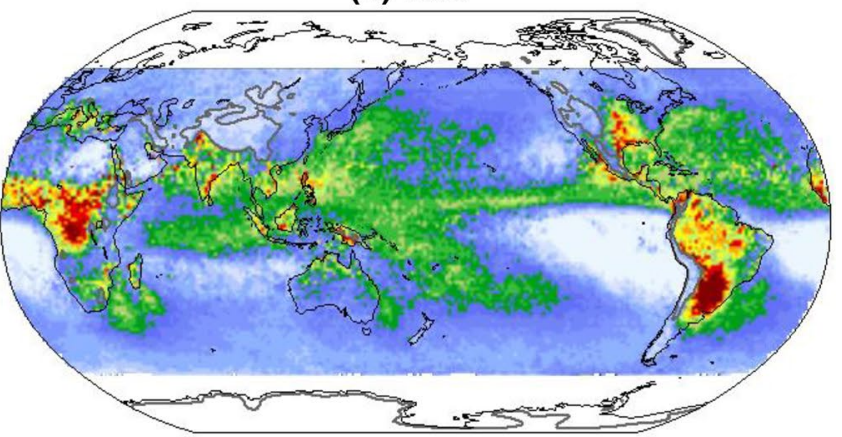

(e) Ann

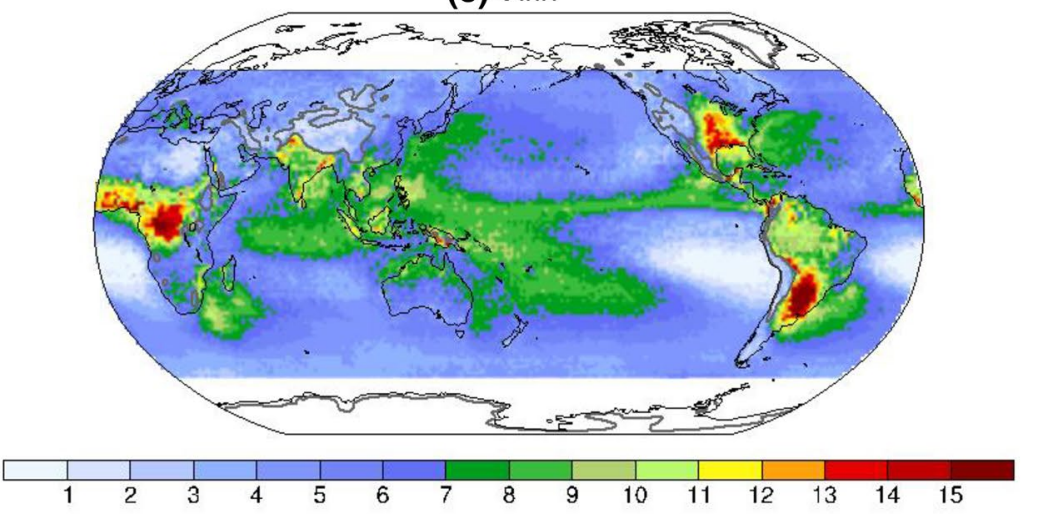

Fig. 2 Climatological extreme hourly precipitation intensity at the 99th percentile level $\left(\mathrm{mm} \mathrm{h}^{-1}\right)$ of CMORPH for January 1998-February 2017 for a winter (DJF), b spring (MAM), c summer (JJA), d autumn (SON), and e the annual mean

(Fig. 6b), evidenced by the fact that TWP-averaged correlations between NWH and Niño3.4 (black bars in Fig. 6a) are negative in winter, summer, and autumn, significant at 0.05 level, while TWP-averaged correlations between the HPI and Niño3.4 (hollow bars in Fig. 6a) are non-significant in all seasons. Similarly, the different response over the TSA is evidenced by the fact that TSA-averaged correlations between the NWH and Niño3.4 (black bars in Fig. 6b) are negative in winter, significant at the 0.05 level, while TSAaveraged correlations between the HPI and Niño3.4 (hollow bars in Fig. 6b) are non-significant for all seasons. In contrast, TMEP-averaged correlations between Niño3.4 and the NWH and HPI are both positive and significant at the 0.05 level, demonstrating the similar response to ENSO variability for NWH and HPI at the sinking branch of the PWC.

We note here that results based on composite analyses where El Niño and La Niña 'events' as defined by NOAA are examined separately (Table S1 and Sect. 5 of the Supplementary Information), are consistent with results reported above (see more details in Figure S6 and Sect. 5 of the Supplementary Information). Similar results are also found with daily precipitation data, as demonstrated in Figure S7 and S8 in the Supplementary Information. Therefore, we can robustly conclude that the response 


\section{Land-Sea Contrast in Hourly, 3-Hourly and Daily Precipiation Intensity Mean Intensity \\ 99th Percentile}

(a) Hourly ( $m m$ hour ${ }^{-1}$ )

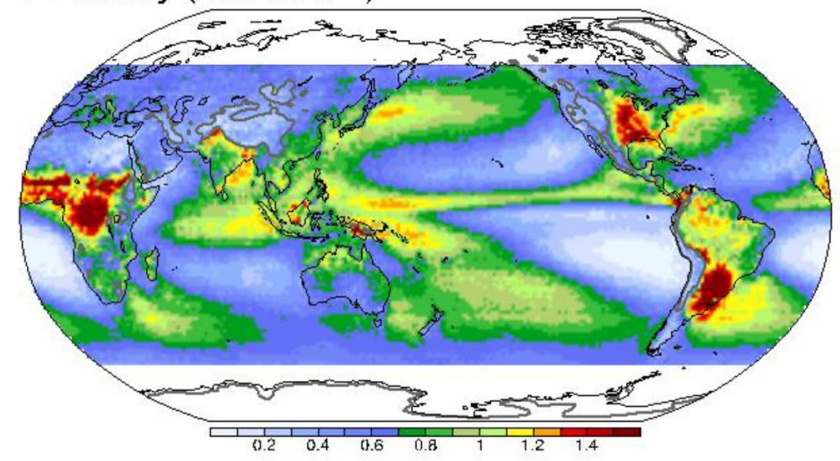

(b) 3-Hourly (mm 3hours ${ }^{-1}$ )

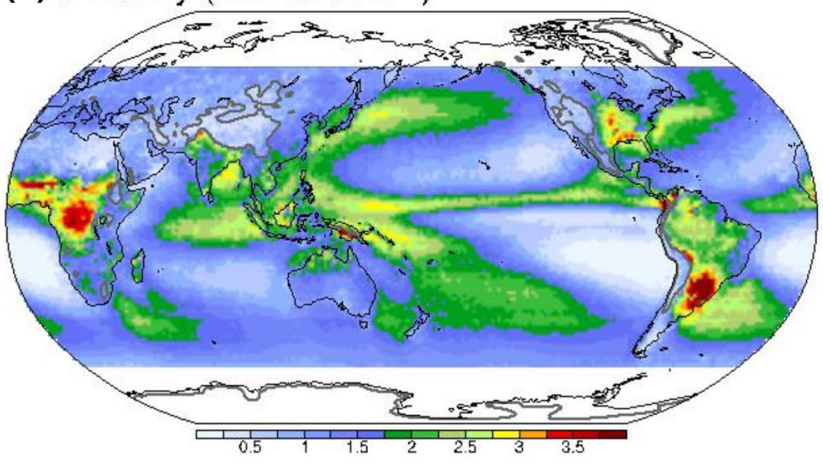

(c) Daily ( $\mathrm{mm}$ day $\left.^{-1}\right)$

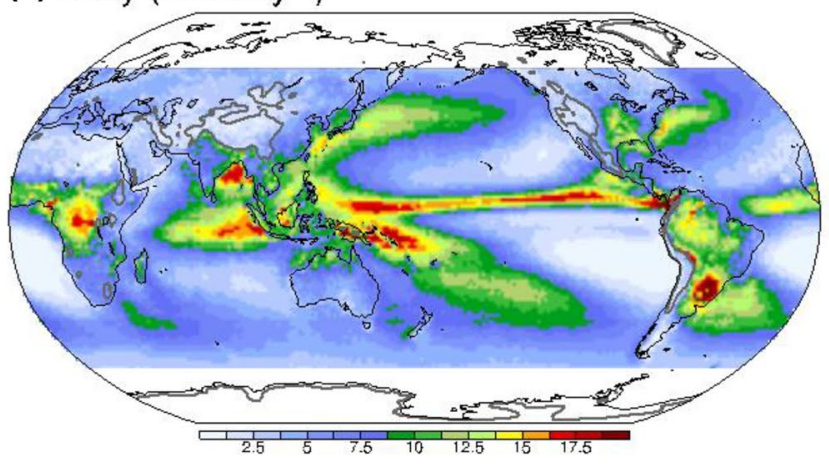

(d) Hourly ( $\mathrm{mm}$ hour $\left.{ }^{-1}\right)$

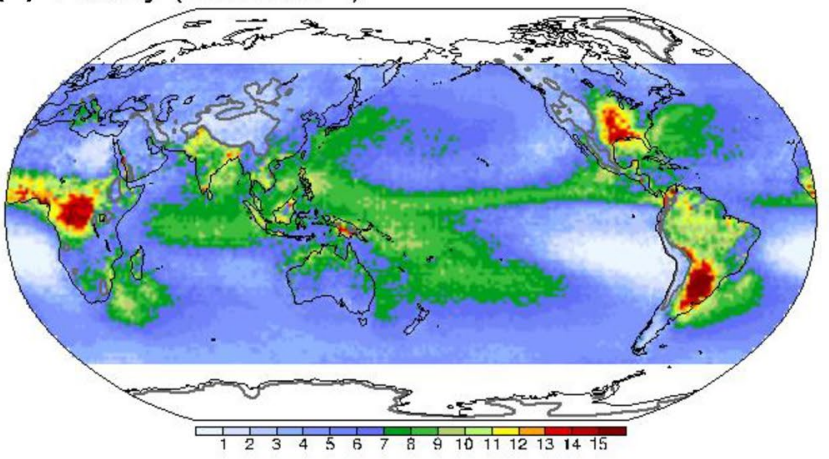

(e) 3-Hourly (mm 3hours ${ }^{-1}$ )

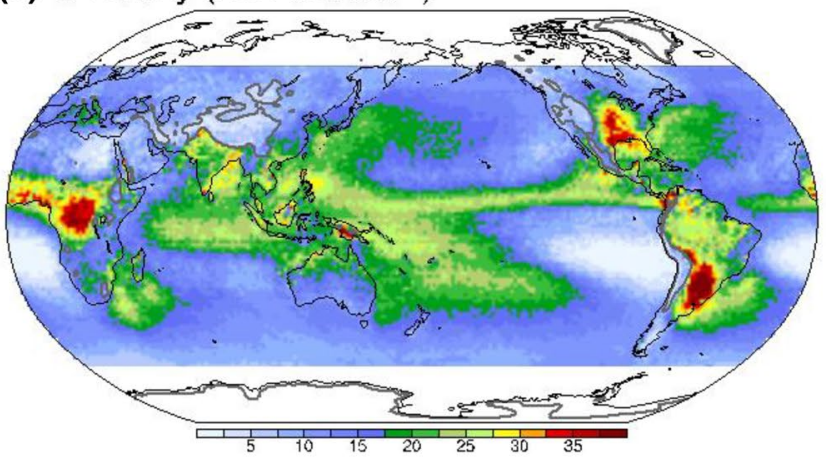

(f) Daily (mm day $\left.{ }^{-1}\right)$

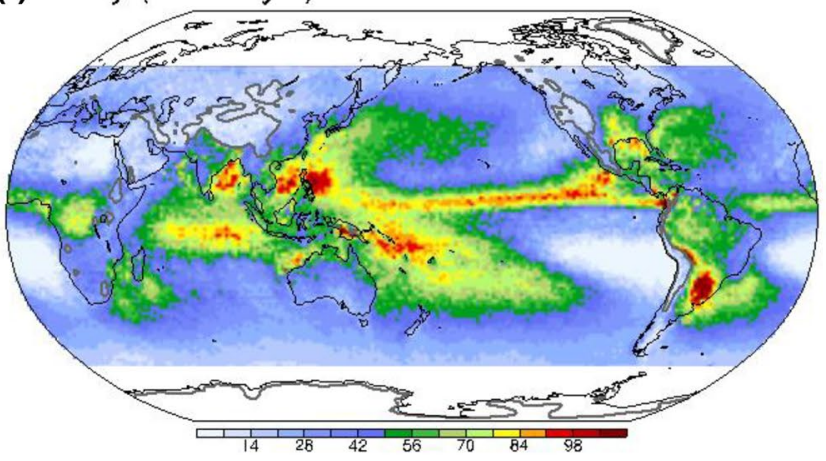

Fig. 3 Global distributions of annual climatological mean and extreme intensity of hourly, 3-h and daily precipitation for January 1998-February 2017 using CMORPH. Left panels (a-c) are for mean intensity, right panels $(\mathbf{d}-\mathbf{f})$ are for extreme intensity (represented by 99th percentile)

of the frequency and intensity of hourly precipitation to ENSO variability is not even across the world. This is particularly apparent at the rising branches of the Pacific and Atlantic Walker Circulations in the tropics. At the sinking branch of the Pacific Walker Circulation, however, the NWH and the HPI response to ENSO variability are comparable to each other (Table 2).

\subsection{Contrasting responses in gauge data}

In this section, we demonstrate that the contrasting response between NWH and HPI to ENSO variability is also observed in gauge data over both tropical and extra-tropical land areas, generally consistent with results of CMORPH over subregions of land areas (figures not shown). 
Table 1 Seasonally calculated spatial correlation among the spatial patterns of climatological-averaged APT, HPI and NWH in CMORPH data for the period January 1998-February 2017

\begin{tabular}{lll}
\hline & HPI vs APT & NWH vs APT \\
\hline Winter (DJF) & 0.76 & 0.94 \\
Spring (MAM) & 0.73 & 0.93 \\
Summer (JJA) & 0.73 & 0.91 \\
Autumn (SON) & 0.71 & 0.93 \\
Annual (ANN) & 0.70 & 0.93 \\
\hline
\end{tabular}

The similarity between two spatial fields is quantified by their spatial Pearson correlation coefficient. Here, all the spatial Pearson correlations are statistically significant at 0.05 level
Fig. 5 Pearson correlations between the Niño3.4 index and monthly mean number of wet hours (NWH, h month ${ }^{-1}$, left column), and monthly mean hourly precipitation intensity (HPI, $\mathrm{mm} \mathrm{h}^{-1}$, right column) for January 1998-February 2017 in CMORPH data. a, b For winter (DJF) months, $\mathbf{c}, \mathbf{d}$ are for spring (MAM) months, $\mathbf{e}, \mathbf{f}$ are for summer (JJA) months, $\mathbf{g}, \mathbf{h}$ are for autumn (SON) months. The colour denotes correlations significant at the 0.05 level. The three black dashed boxes in each panel, respectively represent the tropical western Pacific (TWP; $10^{\circ} \mathrm{S}-15^{\circ} \mathrm{N}, 105^{\circ} \mathrm{E}-145^{\circ} \mathrm{E}$ ), the tropical mideastern Pacific (TMEP; $5^{\circ} \mathrm{S}-5^{\circ} \mathrm{N}, 150^{\circ} \mathrm{E}-280^{\circ} \mathrm{E}$ ) and tropical South America (TSA; $10^{\circ} \mathrm{S}-15^{\circ} \mathrm{N}, 285^{\circ} \mathrm{E}-320^{\circ} \mathrm{E}$ ) domains

\section{Climatological Number of Wet Hours (hour month ${ }^{-1}$ )}

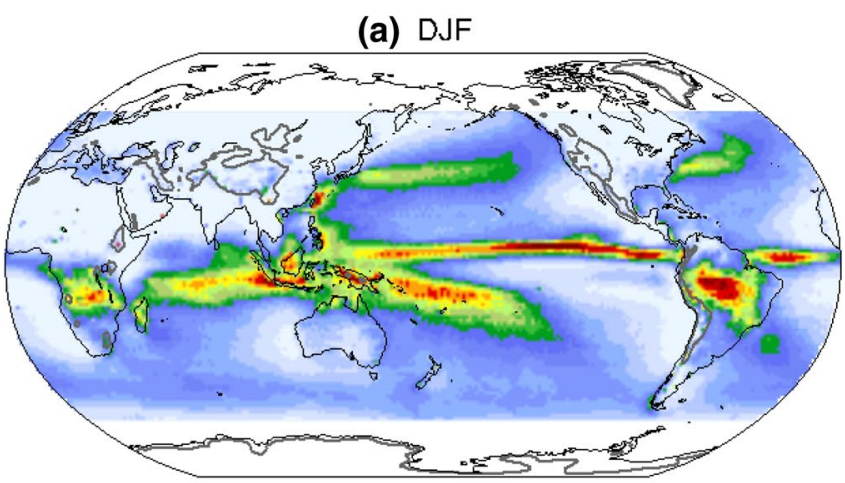

(c) JJA
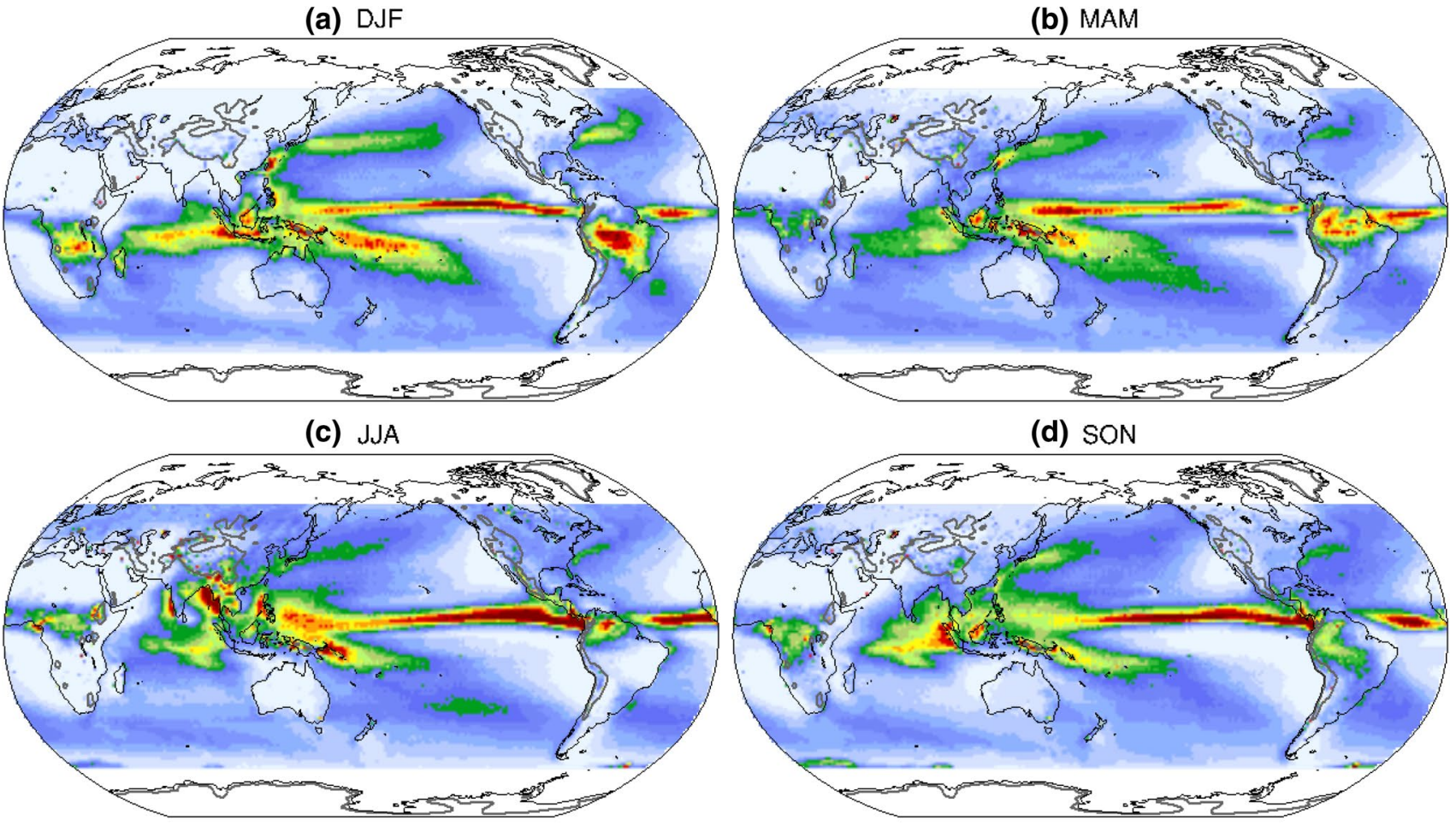

(d) $\mathrm{SON}$

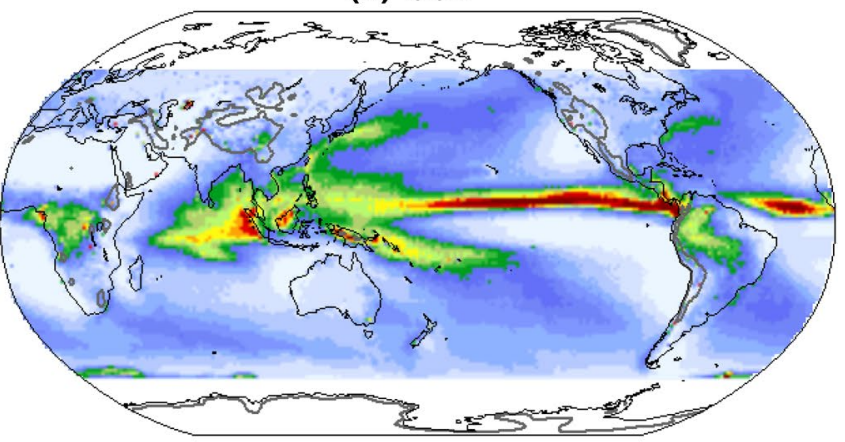

(e) Ann
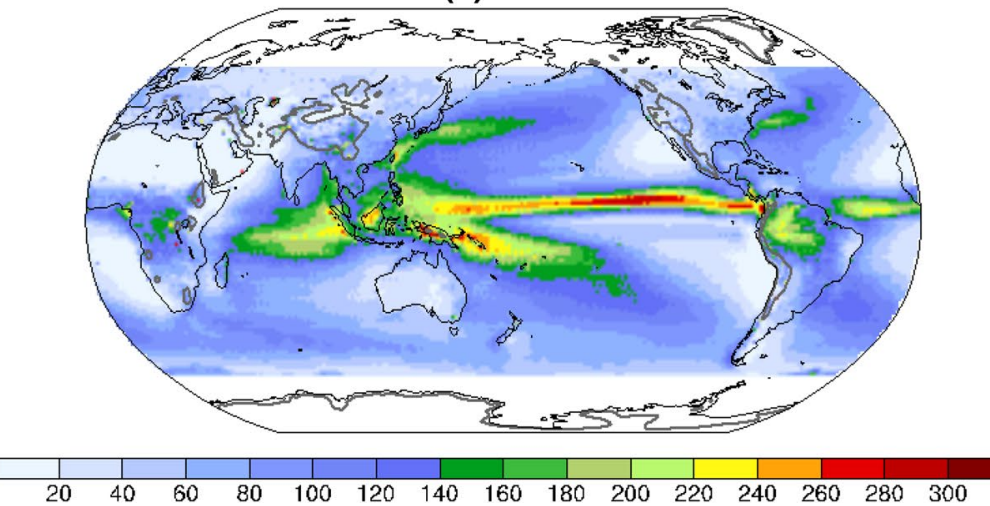

Fig. 4 Climatological-averaged numbers of wet hours (NWH, h month ${ }^{-1}$ ) for CMORPH for January 1998-February 2017 for a winter (DJF), b spring (MAM), c summer (JJA), d autumn (SON), and e the annual mean 


\section{Correlations with Mean Hourly Precipitation Frequency \& Intensity}

(a) NWH, DJF

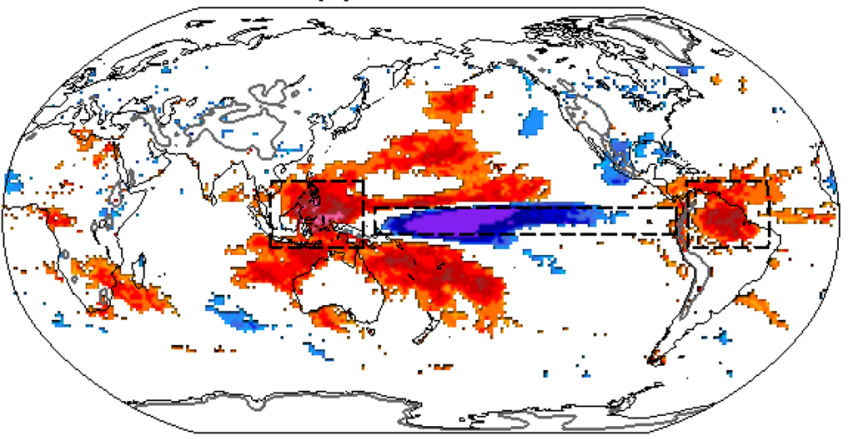

(c) NWH, MAM

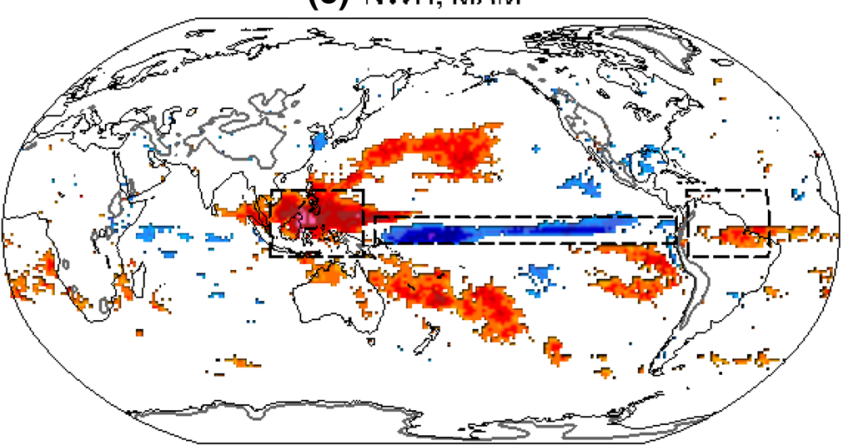

(e) $\mathrm{NWH}$, JJA

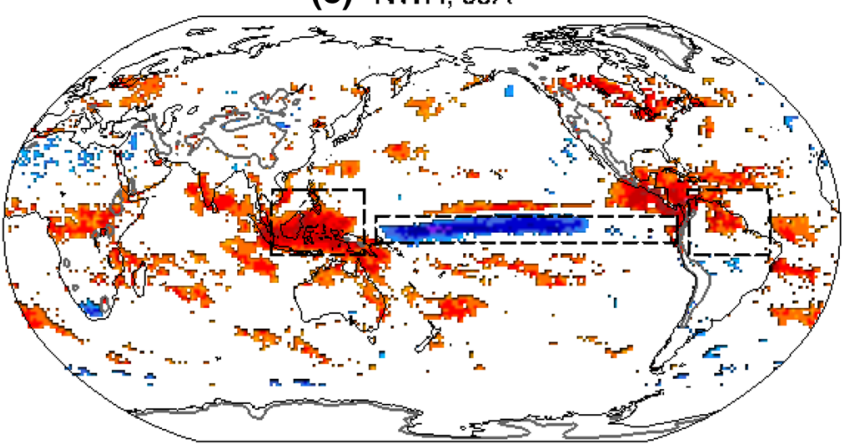

(g) NWH, SON

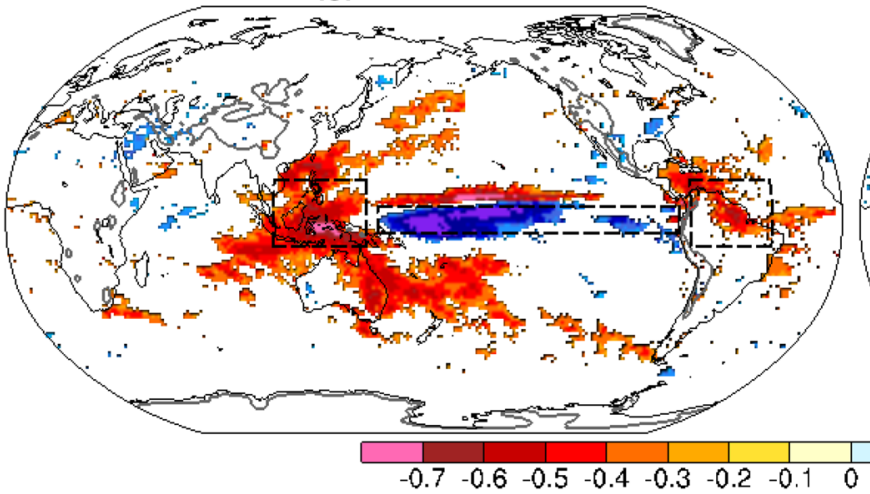

(b) HPI, DJF

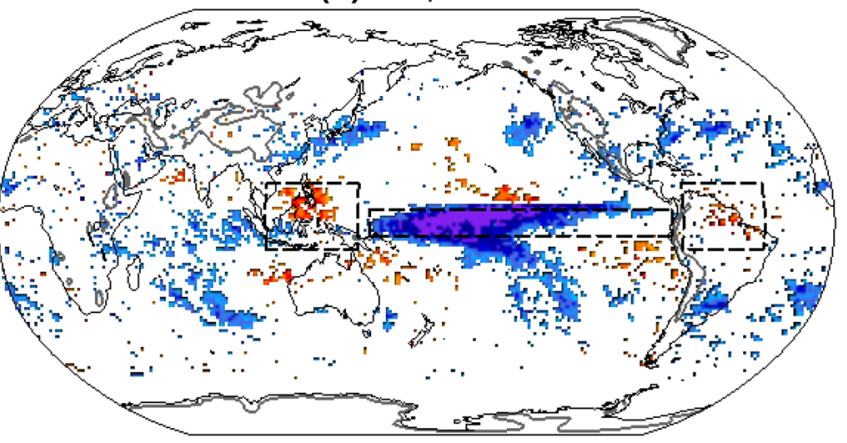

(d) HPI, MAM

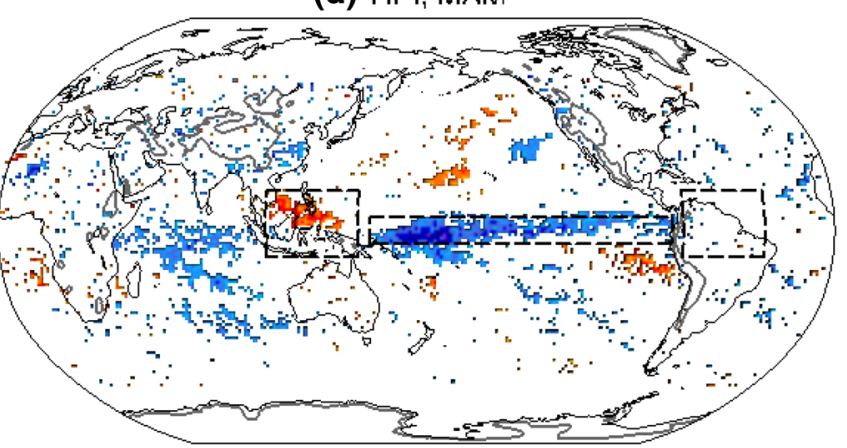

(f) $\mathrm{HPI}, J \mathrm{JA}$

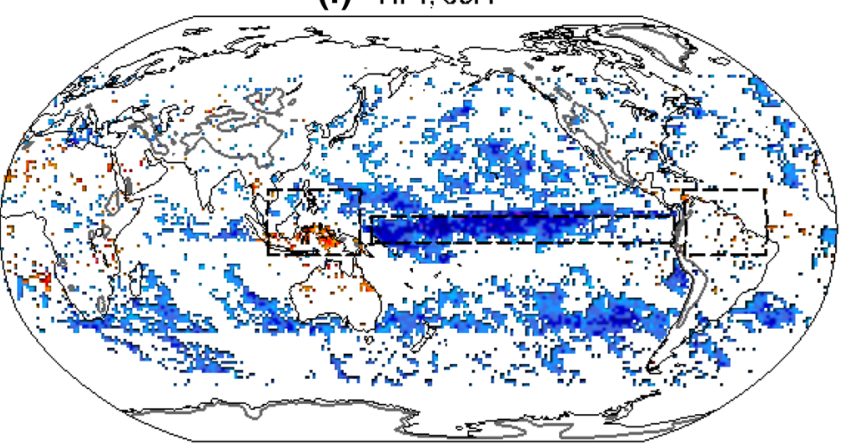

(h) HPI, SON

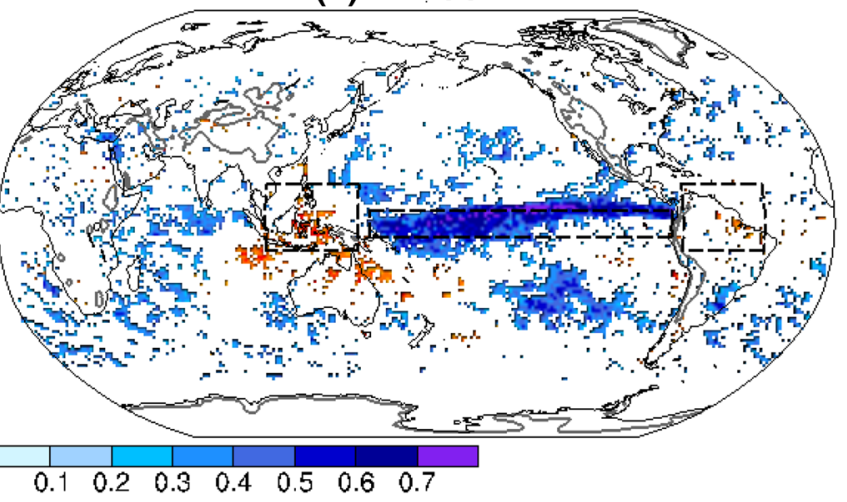




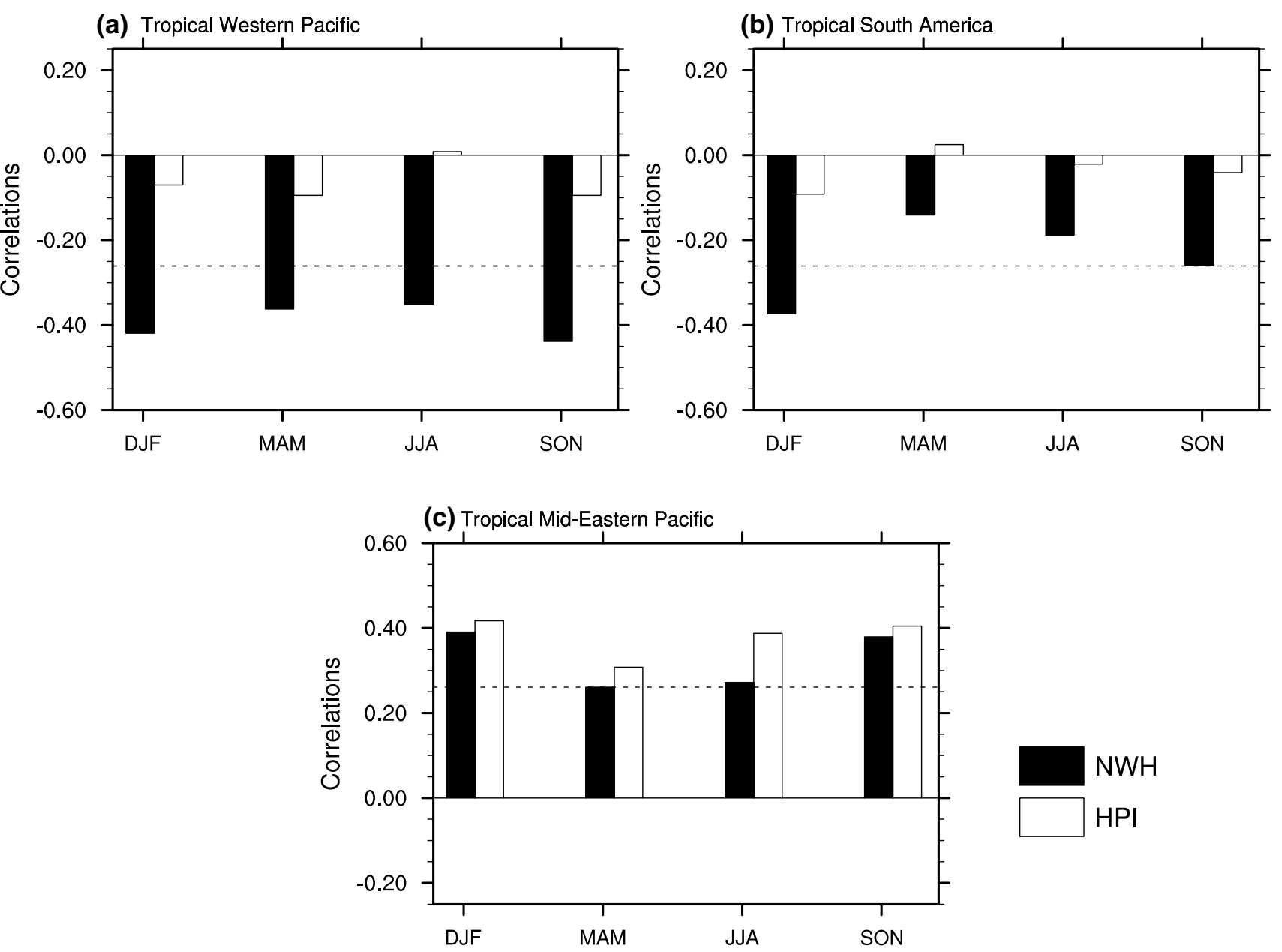

Fig. 6 Average Pearson correlations between the Niño3.4 index and monthly NWH (black bar) and monthly mean HPI (white bar) for a tropical western Pacific (TWP), b tropical South America (TSA), and c tropical mid-eastern Pacific (TMEP) domains for January 1998-

\subsubsection{Tropical gauges}

In the tropics, we examine the GSDR hourly gauges over both Australia and Malaysia, located within the rising branch of the Pacific Walker circulation. Over Australia, we focus on austral spring, the season during which ENSO has the most significant impacts on seasonal accumulated rainfall (Figure S5 in the Supplementary Information). El Niño (La Niña) causes drier (wetter) conditions over northern and eastern Australia in SON (Fig. 7a), in agreement with CMORPH satellite data (Figure S5d in the Supplementary Information). Similarly, Fig. 7b indicates that El Niño (La Niña) causes less (more) NWH over northern and eastern Australia, matching well with the pattern of ENSO's impact on ATP (compare Fig. 7a and 7b). In contrast, the correlation between Niño3.4 and HPI (Fig. 7c) are much weaker, confirming that HPI is less strongly linked with ENSO variability than NWH. Similar results were found in Malaysia
February 2017 in CMORPH data. The three areas are denoted in Fig. 5. The horizontal dashed line in each panel denotes the correlation value significant at the 0.05 level

(Fig. 8). Therefore, the land precipitation gauges in tropical areas support the finding that ENSO's influence on APT at the rising branches of the PWC is mainly through its modulation of hourly rainfall frequency, rather than intensity.

\subsubsection{Extra-tropical gauges}

In the extra-tropics, we examine GSDR data for the USA, Japan and Europe. While APT and the NWH display similar correlation patterns with ENSO (correlation >0.7), the response of HPI presents substantial departures from what we would expect from NWH with correlation $<0.6$, especially in the USA.

We note, however, that the spatial patterns of ENSO's impact vary for different seasons over different sub-regions (Figures S9-14 in the Supplementary Information). In some regions of the USA, Europe and Japan, the impact of ENSO on both HPI and NWH are nearly equivalent in modulating 
Table 2 Similarities between ENSO's seasonal influences on mean APT and hourly precipitation fields (HPI and NWH) for the period January 1998-February 2017

$\begin{array}{ll}\text { Cor (Niño3, APT) vs Cor } & \text { Cor (Niño3, APT) vs } \\ \text { (Niño3, HPI) } & \text { Cor (Niño3, NWH) }\end{array}$

\begin{tabular}{lll}
\hline USA & & \\
DJF & 0.21 & 0.86 \\
MAM & 0.46 & 0.85 \\
JJA & 0.39 & 0.69 \\
SON & 0.37 & 0.85 \\
Japan & & \\
DJF & 0.53 & 0.89 \\
MAM & 0.69 & 0.88 \\
JJA & 0.50 & 0.85 \\
SON & 0.49 & 0.71 \\
Europe & & \\
DJF & 0.61 & 0.85 \\
MAM & 0.52 & 0.79 \\
JJA & 0.59 & 0.74 \\
SON & 0.55 & 0.84 \\
\hline
\end{tabular}

Similar to Table 1 , the similarity is quantified by the spatial correlation coefficient between the two spatial fields. The left (right) column are similarities between the correlation patterns of Niño3.4 with the APT and the correlation patterns of Niño3.4 with the NWH (HPI) in each season for GSDR gauges in the USA, Japan and Europe, respectively

the precipitation total, or the impacts of ENSO on HPI can even be independent or opposite to its impact on either APT or NWH. We provide more details in Sect. 7 of the Supplementary Information. This result indicates the complexity of the associations of hourly precipitation frequency and intensity with ENSO over the extra-tropics, where other influencing factors also exist.

\section{Global contrasting responses of heavy, moderate and light precipitation frequency and intensity to ENSO}

We examine here whether the contrasting response between frequency and intensity also exists across the whole distribution of global hourly precipitation in CMORPH data. As results in all seasons are similar, we only show results for winter (Fig. 9) when the response of tropical precipitation to ENSO is most pronounced. Although the contrasting response exists for the whole distribution of global hourly precipitation, including both 'very heavy' (Fig. 9a vs 9b) and 'heavy' precipitation (Fig. 9c vs 9d), the asymmetry in response is more pronounced for lighter than heavier precipitation (e.g., Figure $9 \mathrm{~g}$ vs $9 \mathrm{~h}$ ), which is more due to differences across the distribution for HPF rather than HPI. Again, the above results can be reproduced with composite analyses
(Table S1 and Sect. 5 of Supplementary Information), and the example of 'very heavy' hourly precipitation is shown in Figure S6c,d (more details in Sect. 5 of the Supplementary Information).

\section{Summary and discussion}

To our knowledge, this is the first study to document a global land-sea contrast in hourly precipitation intensities and the first study to document this using high-quality land-based gauge observations. Despite limited moisture availability over continental surfaces, both climatological-averaged mean and extreme HPI are higher over land, including the mid-latitudes which have previously not been examined. This land-sea contrast in precipitation intensity is not apparent in daily (Pendergrass and Deser 2017, also see Figure S2 and S3 in Sect. 2 of the Supplementary Information) or other coarser-resolution precipitation data, perhaps due to the intermittency of precipitation (Trenberth et al. 2017) that is better measured in hourly precipitation data. We also note that the land-sea contrast in HPI is observed in satellite data. Such data may contain unavoidable biases (e.g., Liu and Allan 2012; Roca 2019; Masunaga et al. 2019) as it can be affected by the very different surface and atmospheric characteristics (e.g., albedo, emissivity, aerosols) of land and ocean regions. However, we notice that the high mean and extreme HPI centers over land match with the active centers of convection (e.g., Figure 11 in Nesbitt et al. 2006), lightning flashes (e.g., Figure 4 in Christian 2003), and the most intense thunderstorms (defined by a combination of satellite-derived convection intensity and lighting flash rate, and radar rainfall intensity) (Zipser et al. 2006). This implies that the land-sea contrast may be associated with physical entities such as mesoscale convective systems (e.g., Schumacher and Johnson 2006) and intense thunderstorms (Zipser et al. 2006). In short, the land-sea contrast in hourly precipitation intensities is not likely to be an artificial feature.

Further analyses are needed to reproduce this land-sea contrast using another metric of precipitation intensity. Indeed, this study uses percentiles conditioned on wet hours and using all hours percentiles may yield different results (Schär et al. 2016). The lower precipitation intensity found over oceans may also be exacerbated by frequent low cloudsrelated drizzle and light precipitation over oceans. Global analyses examining precipitation intensity on sub-daily timescales through the lens of different metrics such as all hours percentiles or annual maxima may provide additional insights on this land-sea contrast.

The land-sea contrast of precipitation intensity may arise due to multiple mechanisms. The three centers of high precipitation intensity over tropical Africa, eastern half of the US and South America match well with regional activity 
Fig. 7 Pearson correlations between the Niño3.4 index and a accumulated precipitation total (APT, mm month ${ }^{-1}$ ), b mean numbers of wet hours (NWH, h month ${ }^{-1}$ ), and $\mathbf{c}$ mean hourly precipitation intensity (HPI, $\mathrm{mm} \mathrm{h}^{-1}$ ) over Australia in austral spring (SON) for January 1998-February 2008 using the GSDR gauge dataset. The black "+" symbol denotes correlations significant at the 0.05 level. The sample size for each season is $\mathbf{5 7 \text { months }}$ (a) APT

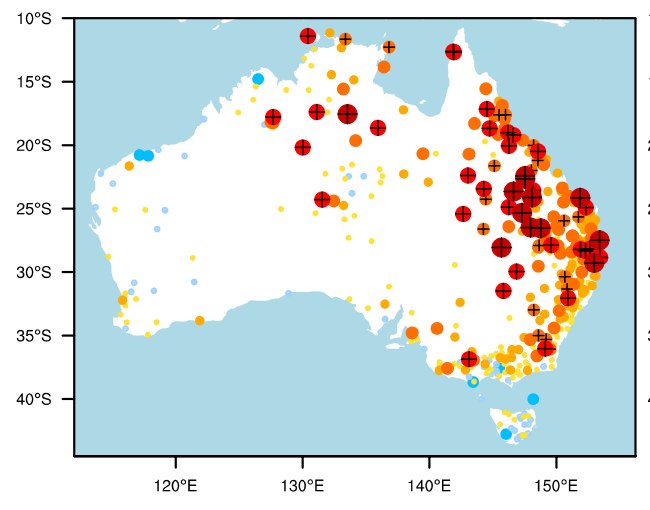

(b) NWH

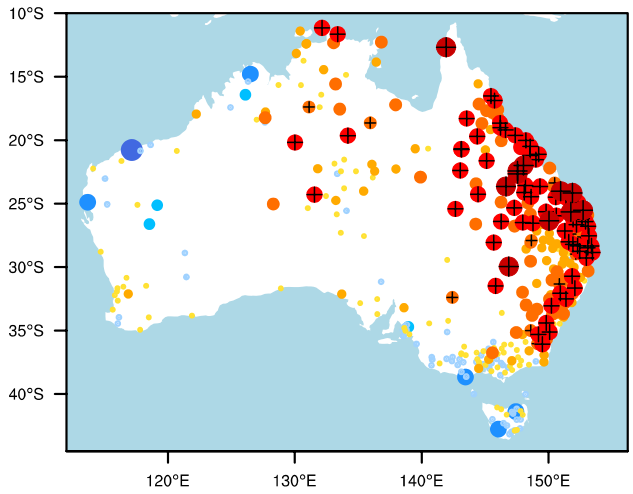

(c) $\mathrm{HPI}$

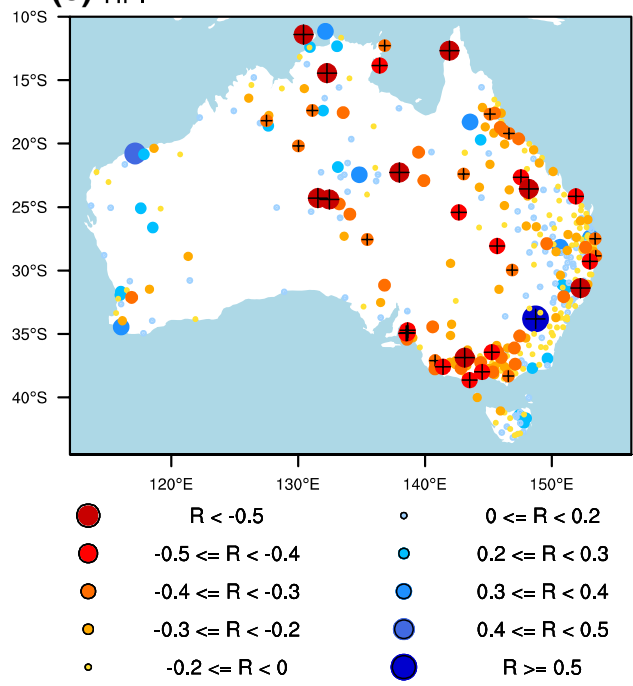

of mesoscale convective systems (e.g., Schumacher and Johnson 2006; Nesbitt et al. 2006; Prein et al. 2017; Puxi et al. 2020) and lightning flashes (e.g., Figure 4 in Christian (2003)). Previous studies have found that precipitation intensity is strongly modulated by both large-scale moisture advection and deep convection due to drier soils (Collow et al. 2014; Yang et al. 2018; Koukoula et al. 2019). The land-sea contrast in HPI may thus relate to continental convection and the stronger diurnal cycle generally observed over lands (e.g., Moron et al. 2010, 2017, 2019; Nesbitt and Zipser 2003; Nesbitt et al. 2006; Puxi et al. 2020). Indeed, that convection differs in intensity between land and ocean over some tropical regions has been previously documented (Biasutti and Yuter 2013) by using instantaneous satellite data, which is consistent with the land-sea contrast in mean and extreme HPI documented here. Alternatively, this contrast may be due to continental aerosols (e.g., Stevens and Feingold 2009; Lin et al. 2018), although the effect of aerosols on rainfall intensity is still highly debated and no consensus has emerged so far (e.g., Stevens and Feingold 2009). Finally, other factors may contribute (e.g., Catto and Pfahl 2013; Tu and Chou 2013; Luo et al. 2016), including orographic effects (e.g., Spreen 1947; Basist et al. 1994; Anders et al. 2006). Further research is therefore needed to fully examine the causes of the land-sea contrast in HPI.

We have also observed a contrasting response of the frequency and intensity of hourly precipitation to ENSO variability, with ENSO conditions generally impacting on the frequency rather than the intensity of hourly precipitation, although there are some local exceptions such as the tropical mid-eastern Pacific, the location of the sinking branch of the PWC. Previously, Pui et al. (2012) noted that most of the changes to daily rainfall totals over east Australia associated with variability in the Southern Oscillation Index appear to stem from changes in the number of wet spells, which supports our conclusions here.

In summary we find:

1. The CMORPH satellite data indicates that there is higher climatological-averaged and extreme Hourly Precipitation Intensity over land areas rather than over oceans. Our study is the first to document this feature over the extra-tropics and with gauge data. In contrast, the climatological-averaged Number of Wet Hours is higher over 
Fig. 8 Correlations between the Niño3.4 index and a accumulated precipitation total (APT, mm month ${ }^{-1}$ ), b mean numbers of wet hours (NWH, $\mathrm{h}$ month ${ }^{-1}$ ), and $\mathbf{c}$ mean hourly precipitation intensity (HPI, $\mathrm{mm} \mathrm{h}^{-1}$ ) over Malaysia in boreal spring (MAM) for 1998February 2017 using the GSDR gauge dataset. The black "+" symbol denotes correlations significant at the 0.05 level. The sample size for each season is 57 months (a) APT

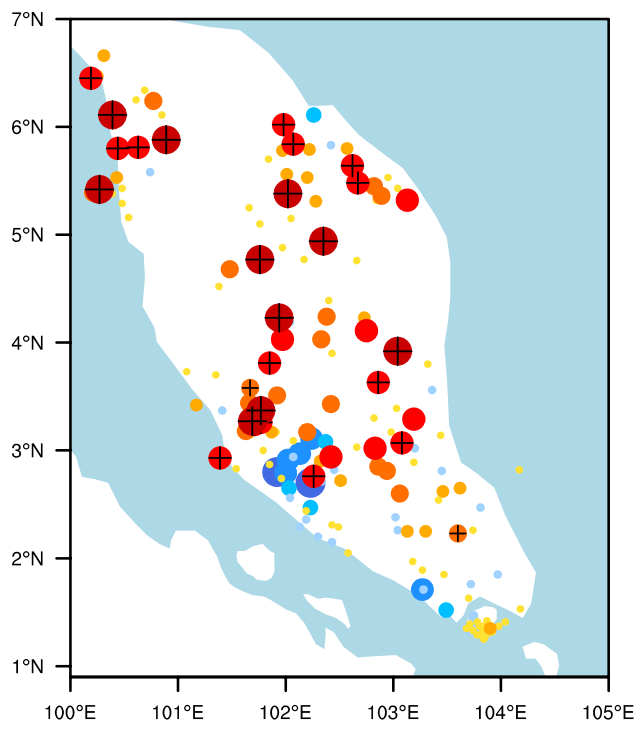

(c) HPI (b) NWH

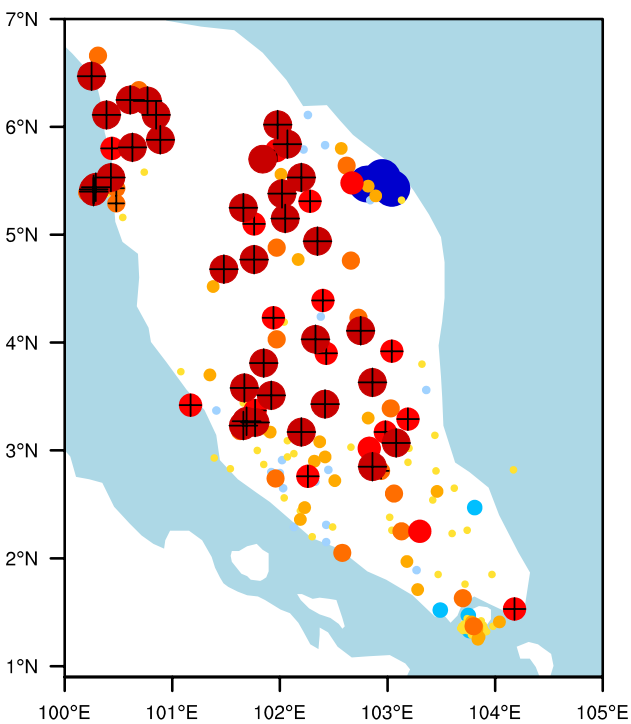

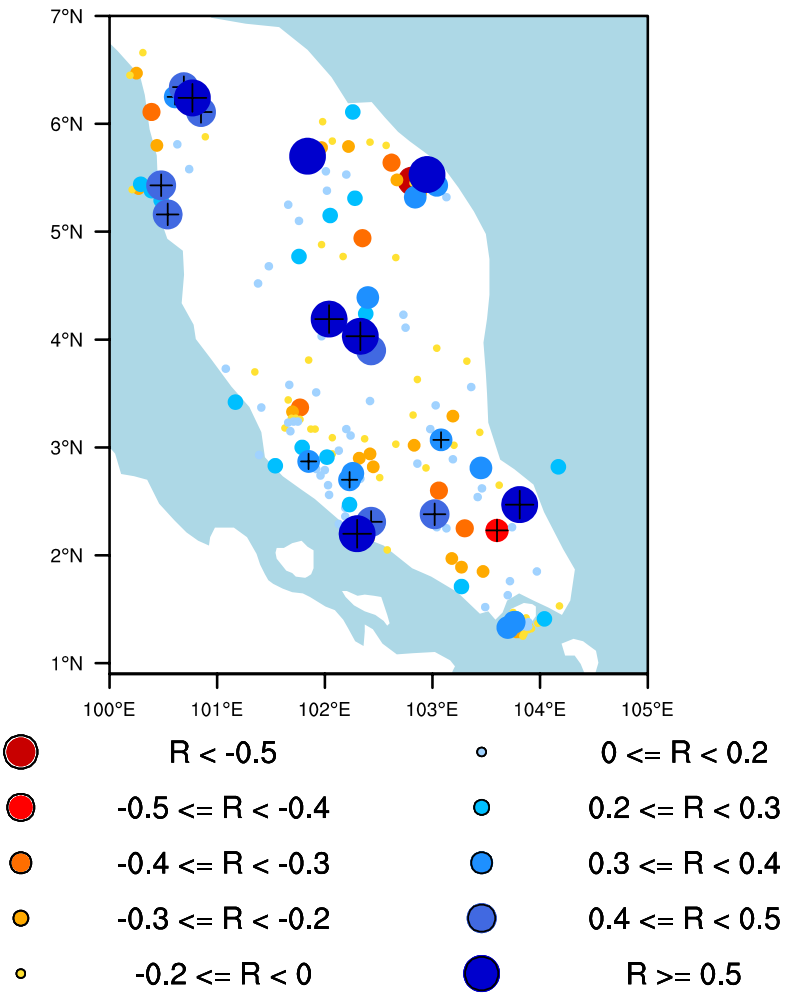

ocean areas, similar to the distribution of the climatological-averaged Accumulated Precipitation Total. This suggests that land precipitation is generally heavier but less frequent than oceanic precipitation, and vice versa.

2. The global distribution of climatological-averaged Number of Wet Hours is the main factor determining the global distribution of the climatological-averaged Accumulated Precipitation Total.
3. ENSO modulates the global Accumulated Precipitation Total mainly through its influence on Number of Wet Hours rather than Hourly Precipitation Intensity. In other words, the frequency and intensity of global hourly precipitation respond differently to ENSO. Contrasting responses of Number of Wet Hours and Hourly Precipitation Intensity to ENSO variability are observed at the rising branches of the Pacific Walker circulation 


\section{Contrasting Responses for Extreme, Moderate and Light Precipitation}

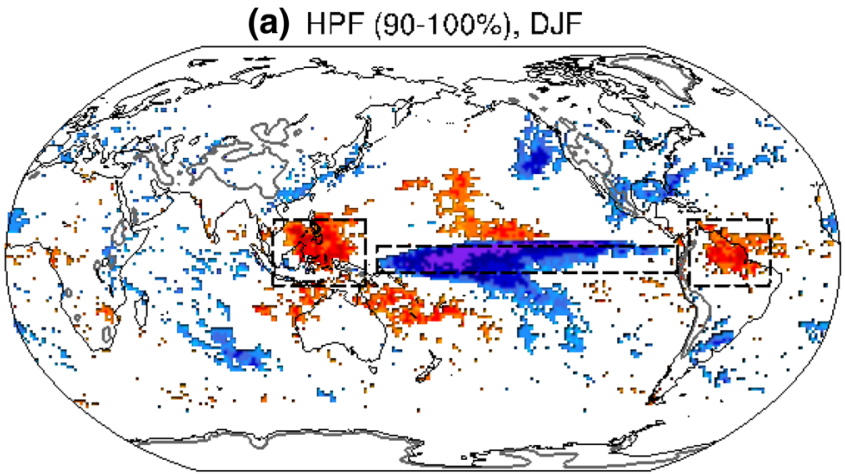

(c) $\operatorname{HPF}(80-100 \%)$. DJF

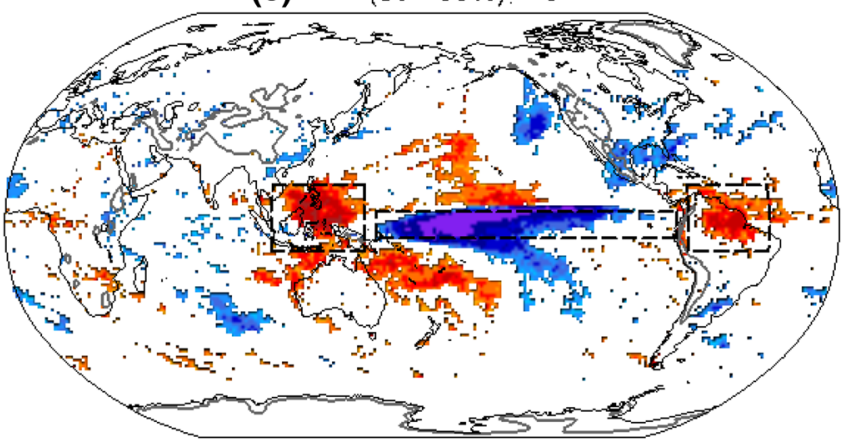

(e) $\operatorname{HPF}(40-60 \%)$, DJF

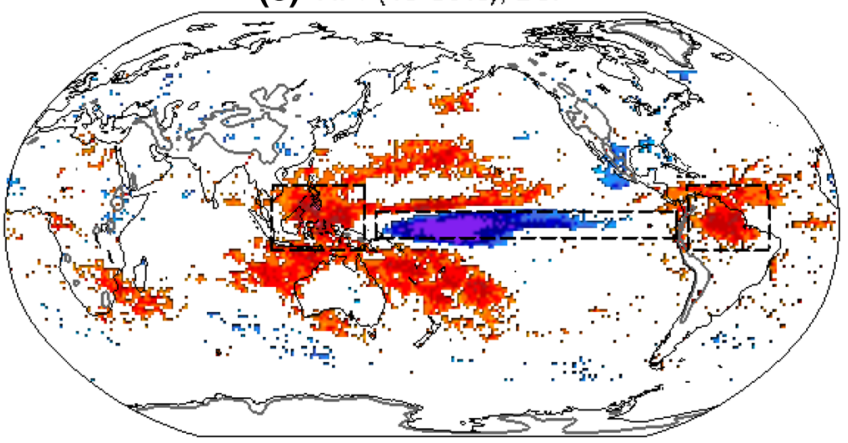

(g) HPF $(0-20 \%)$, DJF

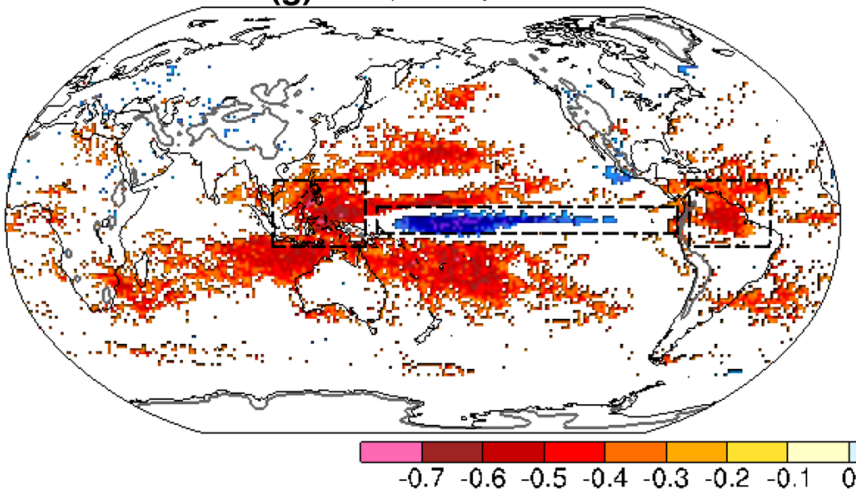

and the Atlantic Walker circulation. El Niño conditions significantly decrease the Number of Wet Hours at the rising branches of the Pacific Walker circulation and

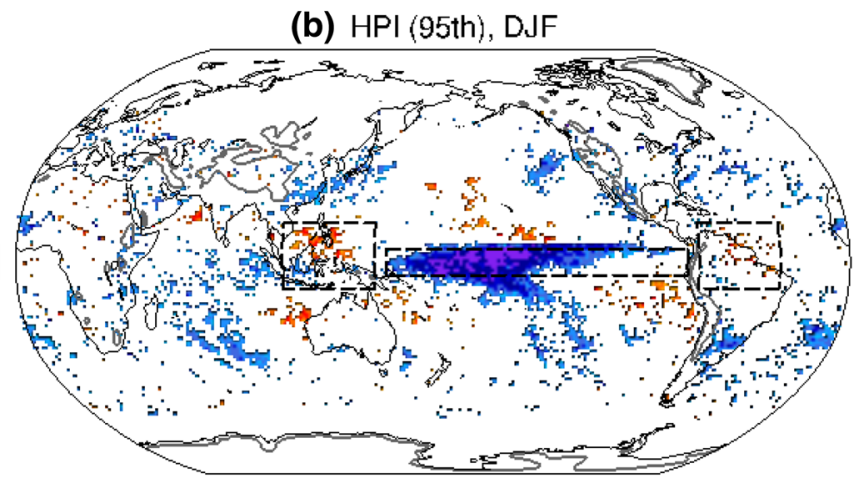

(d) HPI (90th), DJF

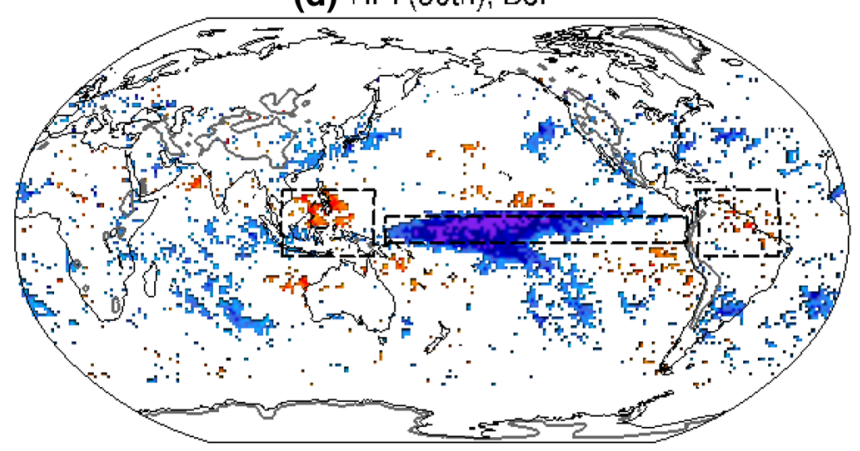

(f) HPI (50th), DJF

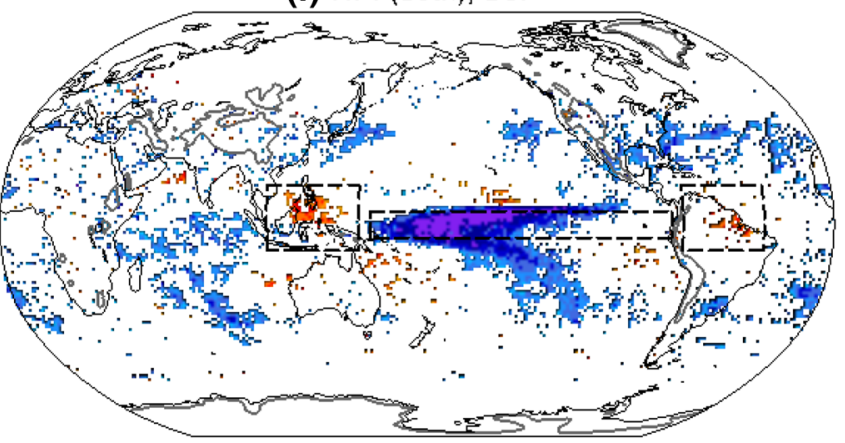

(h) HPI (10th), DJF

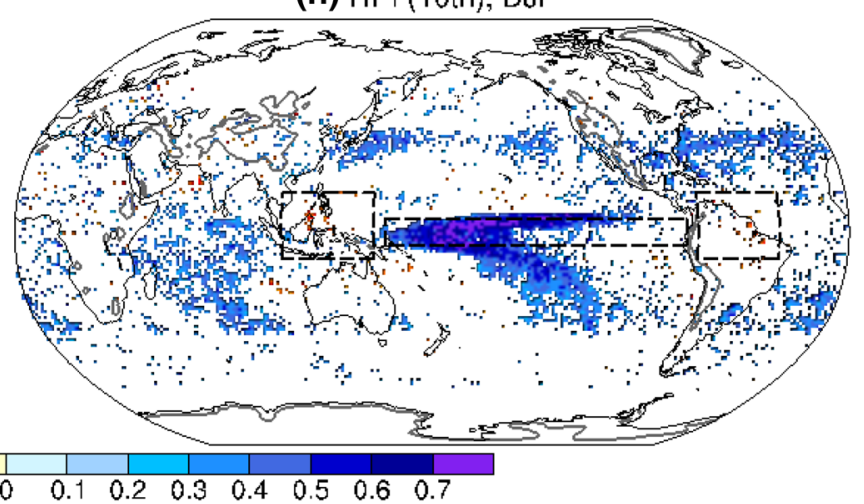

Atlantic Walker circulation, and vice versa, while the Hourly Precipitation Intensity shows a weaker response. We speculate that El Niño phases may inhibit rainfall 
4Fig. 9 Pearson correlations between the Niño3.4 index and HPF (h month ${ }^{-1}$, left column) for percentile bin: a $90-100 \%$ (very heavy), c $80-100 \%$ (heavy), e $40-60 \%$ (moderate), g 0-20\% (light), and the corresponding HPI ( $\mathrm{mm} \mathrm{h}^{-1}$, right column) for the b 95th, d 90th, f 50th, h 10th percentile for January 1998-February 2017 for winter (DJF) months using CMORPH data. The colour denotes correlations significant at the 0.05 level. The three black dashed boxes in each panel respectively represent the tropical western Pacific $\left(10^{\circ} \mathrm{S}-15^{\circ}\right.$ $\left.\mathrm{N}, 105^{\circ} \mathrm{E}-145^{\circ} \mathrm{E}\right)$, tropical mid-eastern Pacific $\left(5^{\circ} \mathrm{S}-5^{\circ} \mathrm{N}, 150^{\circ}\right.$ E-280 $\left.20^{\circ}\right)$ and tropical South America $\left(10^{\circ} \mathrm{S}-15^{\circ} \mathrm{N}, 285^{\circ} \mathrm{E}-320^{\circ}\right.$ E) domains

frequency in the tropical western Pacific through a largescale weakening of the trade-winds and atmospheric convergence due to the weakening of the Walker circulation, while small-scale convective processes, mostly responsible for intense rainfall, may still develop locally independently of ENSO (see Fig. 5). Besides, the biggest magnitude of SST changes associated with ENSO variability are located in the Tropical Mid-Eastern Pacific, suggesting the impacts of the thermal condition changes over this region associated with ENSO variability adds complexity to the contrasting response, which needs further examination but is beyond the scope of this study.

4. The contrasting response in hourly rainfall frequency and intensity to ENSO variability is also seen in the global sub-daily rainfall gauge data in both the tropics and extra-tropics, including Australia, Malaysia, the USA, Japan and Europe.

5. The contrasting responses of the frequency and intensity of hourly precipitation to ENSO are evident across the whole precipitation distribution, but are best manifested in moderate and lighter precipitation amounts.

Our study shows that ENSO's impacts are generally stronger on the frequency than the intensity of precipitation although the response is more symmetric over the sinking branch of the PWC. How we physically explain this contrasting response between intensity and frequency is currently under investigation. Since ENSO dynamically rearranges the wet, ascending portions of the atmospheric circulation with generally less rainfall on average over land during El Niño, it seems expected that rainfall frequency is strongly affected regardless of whether hourly or daily data is used. However, whether the HPI changes are more dependent on the dynamical conditions (such as meteorological regime changes) or thermal conditions (such as SST changes) need further investigation. This might be the key to explaining the contrasting response between intensity and frequency to ENSO variability. Finally, the Walker circulation has been shown to weaken under global warming (Vecchi and Soden 2007). Based on results of our study, the long-term weakening of the Walker circulation could induce higher frequency and greater hourly precipitation intensity over the tropical mid-eastern Pacific. Additional analyses based on climate models would provide estimates of how hourly precipitation frequency and intensity features reported here might change in the future.

Acknowledgements We thank Dr Jian Li (Chinese Academy of Meteorological Sciences) and Dr Andreas Prein (National Center for Atmospheric Research, USA), and three reviewers whose constructive comments and suggestions were helpful to the completion of this work. This research is supported by the European Research Council Grant, INTENSE (ERC-2013-CoG-617329). H.J.F. is also funded by the Wolfson Foundation and the Royal Society as a Royal Society Wolfson Research Merit Award (WM140025) holder. E Kendon gratefully acknowledges funding from the Joint UK BEIS/Defra Met Office Hadley Centre Climate Programme (GA01101).

Open Access This article is licensed under a Creative Commons Attribution 4.0 International License, which permits use, sharing, adaptation, distribution and reproduction in any medium or format, as long as you give appropriate credit to the original author(s) and the source, provide a link to the Creative Commons licence, and indicate if changes were made. The images or other third party material in this article are included in the article's Creative Commons licence, unless indicated otherwise in a credit line to the material. If material is not included in the article's Creative Commons licence and your intended use is not permitted by statutory regulation or exceeds the permitted use, you will need to obtain permission directly from the copyright holder. To view a copy of this licence, visit http://creativecommons.org/licenses/by/4.0/.

\section{References}

Alexander MA, Bladé I, Newman M, Lanzante JR, Lau N-C, Scott JD (2002) The atmospheric bridge: the influence of ENSO teleconnections on air-sea interaction over the global oceans. J Clim 15:2205-2231. https://doi.org/10.1175/15200442(2002)015\%3c2205:tabtio\%3e2.0.co;2

Alexander L, Zhang X, Peterson T, Caesar J, Gleason B, Tank AK, Haylock M, Collins D, Trewin B, Rahimzadeh F (2006) Global observed changes in daily climate extremes of temperature and precipitation. J Geophys Res Atmos 111:20

Ali H, Mishra V (2017) Contrasting response of rainfall extremes to increase in surface air and dewpoint temperatures at urban locations in India. Sci Rep 7:1228. https://doi.org/10.1038/s4159 8-017-01306-1

Allan RP, Soden BJ (2008) Atmospheric warming and the amplification of precipitation extremes. Science 321:1481-1484

Anders AM, Roe GH, Hallet B, Montgomery DR, Finnegan NJ, Putkonen J (2006) Spatial patterns of precipitation and topography in the Himalaya. Spec Pap Geol Soc Am 398:39

Barbero R, Fowler HJ, Lenderink G, Blenkinsop S (2017) Is the intensification of precipitation extremes with global warming better detected at hourly than daily resolutions? Geophys Res Lett 44:2016GL071917. https://doi.org/10.1002/2016g1071917

Barbero R, Abatzoglou JT, Fowler HJ (2019a) Contribution of largescale midlatitude disturbances to hourly precipitation extremes in the United States. Clim Dyn 52:197-208. https://doi.org/10.1007/ s00382-018-4123-5

Barbero R, Fowler HJ, Blenkinsop S, Westra S, Moron V, Lewis E, Lenderink G, Guerreiro S, Li X-F, Kendon EL, Chan S, Villalobos R, Mishra V, Ali H (2019b) A synthesis of hourly and daily 
precipitation extremes in different climatic regions. Weather Clim Extremes. https://doi.org/10.1016/j.wace.2019.100219

Basist A, Bell GD, Meentemeyer V (1994) Statistical relationships between topography and precipitation patterns. J. Clim 7:13051315. https://doi.org/10.1175/1520-0442(1994)007\%3c1305:srbta $\mathrm{p} \% 3 \mathrm{e} 2.0 . \mathrm{co} ; 2$

Biasutti M, Yuter SE (2013) Observed frequency and intensity of tropical precipitation from instantaneous estimates. J Geophys Res Atmos 118:9534-9551. https://doi.org/10.1002/jgrd.50694

Blenkinsop S, Chan SC, Kendon EJ, Roberts NM, Fowler HJ (2015) Temperature influences on intense UK hourly precipitation and dependency on large-scale circulation. Environ Res Lett 10:054021. https://doi.org/10.1088/1748-9326/10/5/054021

Blenkinsop S, Fowler HJ, Barbero R, Chan SC, Guerreiro SB, Kendon E, Lenderink G, Lewis E, Li X-F, Westra S, Alexander L, Allan RP, Berg P, Dunn RJH, Ekström M, Evans JP, Holland G, Jones R, Kjellström E, Klein-Tank A, Lettenmaier D, Mishra V, Prein AF, Sheffield J, Tye MR (2018) The INTENSE project: using observations and models to understand the past, present and future of sub-daily rainfall extremes. Adv Sci Res 15:117-126. https:// doi.org/10.5194/asr-15-117-2018

Catto JL, Pfahl S (2013) The importance of fronts for extreme precipitation. J Geophys Res Atmos 118:10791-710801. https://doi. org/10.1002/jgrd.50852

Chan SC, Kendon EJ, Roberts NM, Fowler HJ, Blenkinsop S (2016) Downturn in scaling of UK extreme rainfall with temperature for future hottest days. Nat Geosci 9:24

Christian HJ (2003) Global frequency and distribution of lightning as observed from space by the Optical Transient Detector. J Geophys Res. https://doi.org/10.1029/2002jd002347

Chung CTY, Power SB (2014) Precipitation response to La Niña and global warming in the Indo-Pacific. Clim Dyn 43:3293-3307. https://doi.org/10.1007/s00382-014-2105-9

Chung CTY, Power SB, Arblaster JM, Rashid HA, Roff GL (2014) Nonlinear precipitation response to El Niño and global warming in the Indo-Pacific. Clim Dyn 42:1837-1856. https://doi. org/10.1007/s00382-013-1892-8

Collow TW, Robock A, Wu W (2014) Influences of soil moisture and vegetation on convective precipitation forecasts over the United States Great Plains. J Geophys Res Atmos 119:9338-9358

Curtis S, Salahuddin A, Adler RF, Huffman GJ, Gu G, Hong Y (2007) Precipitation extremes estimated by GPCP and TRMM: ENSO relationships. J Hydrometeorol 8:678-689

Dai A, Wigley T (2000) Global patterns of ENSO-induced precipitation. Geophys Res Lett 27:1283-1286

Dai A, Fung IY, Genio ADD (1997) Surface observed global land precipitation variations during 1900-88. J Clim 10:2943-2962. https://doi.org/10.1175/1520-0442(1997)010\%3c2943:soglp $\mathrm{v} \% 3 \mathrm{e} 2.0 . \mathrm{co} ; 2$

Gershunov A, Barnett TP (1998) ENSO influence on intraseasonal extreme rainfall and temperature frequencies in the contiguous United States: observations and model results. J Clim 11:1575-1586

Grimm AM, Tedeschi RG (2009) ENSO and extreme rainfall events in South America. J Clim 22:1589-1609. https://doi. org/10.1175/2008jcli2429.1

Gu G, Adler RF (2018) Precipitation intensity changes in the tropics from observations and models. J Clim 31:4775-4790. https:// doi.org/10.1175/jcli-d-17-0550.1

Guerreiro SB, Fowler HJ, Barbero R, Westra S, Lenderink G, Blenkinsop S, Lewis E, Li X-F (2018) Detection of continental-scale intensification of hourly rainfall extremes. Nat Clim Change 8:803-807. https://doi.org/10.1038/s41558-018-0245-3

Huang P (2014) Regional response of annual-mean tropical rainfall to global warming. Atmos Sci Lett 15:103-109
Huang P, Xie S-P (2015) Mechanisms of change in ENSO-induced tropical Pacific rainfall variability in a warming climate. Nat Geosci 8:922-926. https://doi.org/10.1038/ngeo2571

Huang P, Xie S-P, Hu K, Huang G, Huang R (2013) Patterns of the seasonal response of tropical rainfall to global warming. Nat Geosci 20:20

Huffman GJ, Adler RF, Morrissey MM, Bolvin DT, Curtis S, Joyce R, McGavock B, Susskind J (2001) Global precipitation at one-degree daily resolution from multisatellite observations. J Hydrometeorol 2:36-50

Joyce RJ, Xie P (2011) Kalman filter-based CMORPH. J Hydrometeorol 12:1547-1563. https://doi.org/10.1175/JHM-D-11-022.1

Joyce RJ, Janowiak JE, Arkin PA, Xie P (2004) CMORPH: a method that produces global precipitation estimates from passive microwave and infrared data at high spatial and temporal resolution. J Hydrometeorol 5:487-503

Kendon EJ, Roberts NM, Fowler HJ, Roberts MJ, Chan SC, Senior CA (2014) Heavier summer downpours with climate change revealed by weather forecast resolution model. Nat Clim Change 4:570 576. https://doi.org/10.1038/nclimate2258

Koukoula M, Nikolopoulos EI, Kushta J, Bartsotas NS, Kallos G, Anagnostou EN (2019) A numerical sensitivity analysis of soil moisture feedback on convective precipitation. J Hydrometeorol 20:23-44. https://doi.org/10.1175/jhm-d-18-0134.1

Kubota T, Shige S, Hashizume H, Aonashi K, Takahashi N, Seto S, Hirose M, Takayabu YN, Ushio T, Nakagawa K, Iwanami K, Kachi M, Okamoto K (2007) Global precipitation map using satellite-borne microwave radiometers by the GSMaP project: production and validation. IEEE Trans Geosci Remote Sens 45:2259-2275. https://doi.org/10.1109/TGRS.2007.895337

Lenderink G, Van Meijgaard E (2008) Increase in hourly precipitation extremes beyond expectations from temperature changes. Nat Geosci 1:511-514

Lenderink G, Barbero R, Loriaux JM, Fowler HJ (2017) Super-Clausius-Clapeyron scaling of extreme hourly convective precipitation and its relation to large-scale atmospheric conditions. J Clim 30:6037-6052. https://doi.org/10.1175/JCLI-D-16-0808.1

Lestari S, Hamada J-I, Syamsudin F, Matsumoto J, Yamanaka MD (2016) ENSO influences on rainfall extremes around Sulawesi and Maluku Islands in the Eastern Indonesian Maritime Continent. SOLA 12:37-41

Lewis E, Fowler HJ, Alexander L, Dunn R, McClean F, Barbero R, Guerreiro S, Li X-F, Blenkinsop S (2019) GSDR: a global sub-daily rainfall dataset. J Clim 32(15):4715-4729. https://doi. org/10.1175/JCLI-D-18-0143.1

Li X-F, Yu J, Li Y (2013) Recent summer rainfall increase and surface cooling over Northern Australia since the late 1970s: a response to warming in the tropical Western Pacific. J. Climate 26:7221-7239. https://doi.org/10.1175/JCLI-D-12-00786.1

Lin L, Wang Z, Xu Y, Fu Q, Dong W (2018) Larger sensitivity of precipitation extremes to aerosol than greenhouse gas forcing in CMIP5 models. J Geophys Res Atmos 123:8062-8073

Liu C, Allan RP (2012) Multisatellite observed responses of precipitation and its extremes to interannual climate variability. J Geophys Res Atmos. https://doi.org/10.1029/2011jd016568

Luo Y, Wu M, Ren F, Li J, Wong W-K (2016) Synoptic situations of extreme hourly precipitation over China. J Clim 29:8703-8719. https://doi.org/10.1175/JCLI-D-16-0057.1

Lyon B, Barnston AG (2005) ENSO and the spatial extent of interannual precipitation extremes in tropical land areas. J Clim 18:5095-5109

Masunaga H, Schröder M, Furuzawa FA, Kummerow C, Rustemeier E, Schneider U (2019) Inter-product biases in global precipitation extremes. Environ Res Lett 14:125016. https://doi. org/10.1088/1748-9326/ab5da9 
Moron V, Robertson AW, Qian J-H (2010) Local versus regional-scale characteristics of monsoon onset and post-onset rainfall over Indonesia. Clim Dyn 34:281-299

Moron V, Robertson AW, Pai D (2017) On the spatial coherence of sub-seasonal to seasonal Indian rainfall anomalies. Clim Dyn 49:3403-3423

Moron V, Barbero R, Evans J, Westra S, Fowler HJ (2019) Weather types and hourly to multi-day rainfall characteristics in Tropical Australia. J Clim 32:3983-4011. https://doi.org/10.1175/ JCLI-D-18-0384.1

Nesbitt SW, Zipser EJ (2003) The diurnal cycle of rainfall and convective intensity according to three years of TRMM measurements. J Clim 16:1456-1475. https://doi. org/10.1175/1520-0442-16.10.1456

Nesbitt SW, Cifelli R, Rutledge SA (2006) Storm morphology and rainfall characteristics of TRMM precipitation features. Mon Weather Rev 134:2702-2721. https://doi.org/10.1175/mwr3200.1

Pendergrass AG, Deser C (2017) Climatological characteristics of typical daily precipitation. J Clim 30:5985-6003. https://doi. org/10.1175/jcli-d-16-0684.1

Power S, Delage F, Chung C, Kociuba G, Keay K (2013) Robust twenty-first-century projections of El Niño and related precipitation variability. Nature 502:541. https://doi.org/10.1038/natur e12580

Prein AF, Rasmussen RM, Ikeda K, Liu C, Clark MP, Holland GJ (2017) The future intensification of hourly precipitation extremes. Nat Clim Change 7:48-52. https://doi.org/10.1038/nclimate3168

Pui A, Sharma A, Santoso A, Westra S (2012) Impact of the El NiñoSouthern Oscillation, Indian Ocean Dipole, and southern annular mode on daily to subdaily rainfall characteristics in East Australia. Mon Weather Rev 140:1665-1682. https://doi.org/10.1175/mwrd-11-00238.1

Puxi L, Moseley C,Prein AF, Chen H, Li J, Furtado K, Zhou T (2020) Mesoscale convective systems precipitation characteristics over East Asia. Part I:regional differences and seasonal variations. J Clim (submitted)

Rayner N, Parker DE, Horton E, Folland C, Alexander L, Rowell D, Kent E, Kaplan A (2003) Global analyses of sea surface temperature, sea ice, and night marine air temperature since the late nineteenth century. J Geophys Res Atmos 108:20

Roca R (2019) Estimation of extreme daily precipitation thermodynamic scaling using gridded satellite precipitation products over tropical land. Environ Res Lett 14:095009. https://doi. org/10.1088/1748-9326/ab35c6

Ropelewski CF, Halpert MS (1987) Global and regional scale precipitation patterns associated with the El Niño/Southern Oscillation. Mon Weather Rev 115:1606-1626. https://doi.org/10.1175/15200493(1987)115\%3c1606:garspp\%3e2.0.co;2

Schär C, Ban N, Fischer EM, Rajczak J, Schmidli J, Frei C, Giorgi F, Karl TR, Kendon EJ, Tank AMGK, O'Gorman PA, Sillmann J, Zhang X, Zwiers FW (2016) Percentile indices for assessing changes in heavy precipitation events. Clim Change 137:201-216. https://doi.org/10.1007/s10584-016-1669-2

Schumacher RS, Johnson RH (2006) Characteristics of U.S. extreme rain events during 1999-2003. Weather Forecast 21:69-85. https ://doi.org/10.1175/waf900.1

Seager R, Naik N, Vecchi GA (2010) Thermodynamic and dynamic mechanisms for large-scale changes in the hydrological cycle in response to global warming. J Clim 23:4651-4668. https://doi. org/10.1175/2010JCLI3655.1

Seager R, Naik N, Vogel L (2011) Does global warming cause intensified interannual hydroclimate variability? J Clim 25:3355-3372. https://doi.org/10.1175/JCLI-D-11-00363.1
Shen Y, Xiong A, Wang Y, Xie P (2010) Performance of high-resolution satellite precipitation products over China. J Geophys Res Atmos 115:D02114. https://doi.org/10.1029/2009JD012097

Shen Y, Zhao P, Pan Y, Yu J (2014) A high spatiotemporal gaugesatellite merged precipitation analysis over China. J Geophys Res 119:3063-3075

Spreen WC (1947) A determination of the effect of topography upon precipitation. Eos Trans Am Geophys Union 28:285-290

Stevens B, Feingold G (2009) Untangling aerosol effects on clouds and precipitation in a buffered system. Nature 461:607-613

Sun Q, Miao C, Duan Q, Ashouri H, Sorooshian S, Hsu KL (2018) A review of global precipitation data sets: data sources, estimation, and intercomparisons. Rev Geophys 56:79-107. https://doi. org/10.1002/2017RG000574

Trenberth KE, Shea DJ (2005) Relationships between precipitation and surface temperature. Geophys Res Lett 32:L14703. https:// doi.org/10.1029/2005GL022760

Trenberth KE, Zhang Y, Gehne M (2017) Intermittency in precipitation: duration, frequency, intensity, and amounts using hourly data. J Hydrometeorol 18:1393-1412. https://doi.org/10.1175/ jhm-d-16-0263.1

Tu J-Y, Chou C (2013) Changes in precipitation frequency and intensity in the vicinity of Taiwan: typhoon versus non-typhoon events. Environ Res Lett 8:014023

Vecchi GA, Soden BJ (2007) Global warming and the weakening of the tropical circulation. J. Clim 20:4316-4340. https://doi. org/10.1175/JCLI4258.1

Whan K, Zwiers F (2016) The impact of ENSO and the NAO on extreme winter precipitation in North America in observations and regional climate models. Clim Dyn. https://doi.org/10.1007/ s00382-016-3148-x

Xuereb K, Jakob D (2014) The relationship between ENSO/IOD and rainfall extremes in Australia. In: Hydrology and water resources symposium 2014, Engineers Australia, p 477

Yang L, Sun G, Zhi L, Zhao J (2018) Negative soil moisture-precipitation feedback in dry and wet regions. Sci Rep 8:4026

Yu R, Li J (2012) Hourly rainfall changes in response to surface air temperature over eastern contiguous China. J Clim 25:6851-6861. https://doi.org/10.1175/JCLI-D-11-00656.1

Yu J, Shen Y, Pan Y, Zhao P, Zhou Z (2013) Improvement of satellitebased precipitation estimates over China based on probability density function matching method. J Appl Meteorol Sci 24:544-553 (in Chinese)

Yu J, Shen Y, Pan Y, Xiong A (2015) Comparative assessment for daily merged precipitation dataset and the world's popular counterparts over China. Acta Meteorol Sin 73:394-410 (in chinese)

Zar JH (1984) Biostatistical analysis. Prentice Hall, Upper Saddle River, $\mathrm{p} 718$

Zhang X, Wang J, Zwiers FW, Groisman PY (2010) The influence of large-scale climate variability on winter maximum daily precipitation over North America. J Clim 23(11):2902-2915

Zipser EJ, Cecil DJ, Liu C, Nesbitt SW, Yorty DP (2006) Where are the most intense thunderstorms on Earth? Bull Am Meteorol Soc 87:1057-1072

Zorzetto E, Marani M (2019) Downscaling of rainfall extremes from satellite observations. Water Resour Res 55:156-174. https://doi. org/10.1029/2018wr022950

Publisher's Note Springer Nature remains neutral with regard to jurisdictional claims in published maps and institutional affiliations. 